\title{
Synthesis and In Vivo Evaluation of 5-Chloro-5-benzobarbiturates as New Central Nervous System Depressants
}

\author{
Andreia A. Vieira, Niele M. Gomes, Maria E. Matheus, Patricia D. Fernandes and \\ José D. Figueroa-Villar* \\ ${ }^{a}$ Medicinal Chemistry Group, Department of Chemistry, Instituto Militar de Engenharia, \\ Praça General Tibúrcio 80, 22290-270, Rio de Janeiro-RJ, Brazil. \\ ${ }^{b}$ Laboratório de Farmacologia da Inflamação e do Óxido Nítrico, Instituto de Ciências Biomédicas, Universidade \\ Federal do Rio de Janeiro, Av. Carlos Chagas Filho 373, CCS, Bloco J, Rio de Janeiro-RJ, Brazil
}

\begin{abstract}
Uma nova família de barbituratos, ácidos 5-cloro-5-benzilbarbitúricos, foi preparada usando um método simples e eficiente a partir de aldeídos aromáticos e ácido barbitúrico, seguido de redução e cloração usando ácido tricloroisocianúrico, com rendimento global de 53 a 70\%. Por avaliação in vivo com camundongos, os produtos apresentaram atividade tranqüilizante.
\end{abstract}

A new family of barbiturates, 5-chloro-5-benzylbarbituric acids, was prepared using a simple efficient synthetic method from aromatic aldehydes and barbituric acid, followed by reduction and chlorination with trichloro-isocyanuric acid, affording overall yields of 53 to $70 \%$. The in vivo evaluation with mice showed that these compounds present tranquilizing activity.

Keywords: 5-chloro-5-benzylbarbituric acids, tranquilizers, benzylidenebarbiturates, trichloroisocyanuric acid, rota-rod tests

\section{Introduction}

Barbiturates are very well known drugs with activity at the central nervous system (CNS), with specific activity as anticonvulsants, anxiolytics, tranquilizers and sedatives-hypnotics. ${ }^{1}$ The mechanism of action of barbiturates at the CNS is not well known, but it has been shown that they are able to interfere with acetylcholine, norepinephrine and glutamate activity and also that they can inhibit the calcium uptake of nerve terminals, thus allowing their use as analgesics. ${ }^{2,3}$ In fact, today barbiturates are commonly used to induce anesthesia in surgery procedures. They are also known as GABA-mimetics, thus functioning as agonists of GABA receptors. ${ }^{3,4}$

For many years the barbiturates were the main drugs used to cause effects on the CNS. However, after the discovery of the very effective benzodiazepines, their use became less common simply because benzodiazepines have less potential for lethal overdoses. ${ }^{5,6}$ The main cause of death by overdoses of barbiturates is respiratory failure, because they are very potent respiratory depressants. Today, the main uses of barbiturates are the induction

\footnotetext{
*e-mail: figueroa@ime.eb.br
}

of anesthesia and for the treatment of refractory status epilepticus. $^{7}$

Regarding the significant historical and actual use of barbiturates as neurological drugs, and the importance of this type of disease in the actual condition of mankind, we developed a very simple new family of barbiturates with CNS activity. Interestingly, 5-chlorobarbituric acid and their derivatives have been rarely investigated. The only similar compounds that have been reported as anticonvulsants are the 5-chloro-5-phenyl barbiturates. ${ }^{8}$ Surprisingly, 5-benzyl-5-chlorobarbituric acids have not been reported in the literature. We developed a very simple and efficient method for the preparation of this new family of barbiturates as potential tranquilizers.

\section{Results and Discussion}

Our strategy for the preparation of 5-benzyl-5chlorobabiturates was based on the use of benzylidenebarbiturates as intermediates, which are very easy to prepare. ${ }^{9-12}$ Benzylidenebarbiturates are employed in several well known reactions in the literature $\mathrm{e}^{10,13-17}$ and have even been used as methionine aminopeptidase inhibitors. ${ }^{18}$ The preparation of the 5-chloro-5-benzolbarbiturates was 


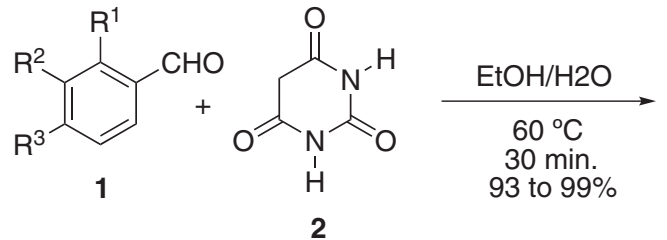

1a $R^{1}=R^{2}=R^{3}=H$

1b $R^{1}=R^{2}=\mathrm{H}, \mathrm{R}^{3}=\mathrm{OCH}_{3}$

1c $R^{1}=\mathrm{H}, \mathrm{R}^{2}$ and $\mathrm{R}^{3}=\mathrm{OCH}_{2} \mathrm{O}$

1d $\mathrm{R}^{1}=\mathrm{OCH}_{2} \mathrm{CH}_{3}, \mathrm{R}^{2}=\mathrm{R}^{3}=\mathrm{H}$

1e $\mathrm{R}^{1}=\mathrm{R}^{2}=\mathrm{H}, \mathrm{R}^{3}=\mathrm{Cl}$

if $\mathrm{R}^{1}=\mathrm{Cl}, \mathrm{R}^{2}=\mathrm{R}^{3}=\mathrm{H}$
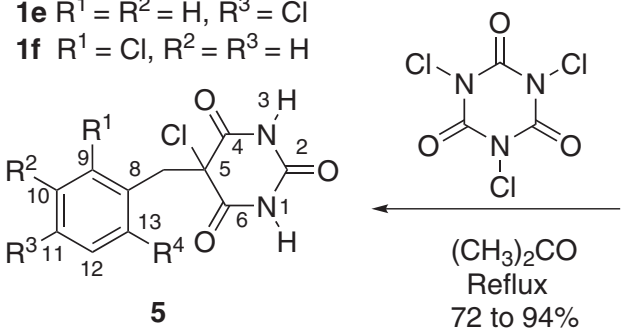

6a $R^{1}=R^{2}=R^{3}=R^{4}=H$

6b $\mathrm{R}^{1}=\mathrm{R}^{2}=\mathrm{H}, \mathrm{R}^{4}=\mathrm{Cl}, \mathrm{R}^{3}=\mathrm{OCH}_{3}$

6c $\mathrm{R}^{1}=\mathrm{H}, \mathrm{R}^{2}$ and $\mathrm{R}^{3}=\mathrm{OCH}_{2} \mathrm{O}, \mathrm{R}^{4}=\mathrm{Cl}$

6d R $\mathrm{R}^{4}=\mathrm{OCH}_{2} \mathrm{CH}_{3}, \mathrm{R}^{2}=\mathrm{Cl}, \mathrm{R}^{1}=\mathrm{R}^{3}=\mathrm{H}$

$6 e \mathrm{R}^{1}=\mathrm{R}^{2}=\mathrm{R}^{4}=\mathrm{H}, \mathrm{R}^{3}=\mathrm{Cl}$

6f $\mathrm{R}^{1}=\mathrm{Cl}, \mathrm{R}^{2}=\mathrm{R}^{3}=\mathrm{R}^{4}=\mathrm{H}$<smiles>[R]c1ccc(/C=C2/C(=O)NC(=O)NC2NC)c([R])c1[R]</smiles>

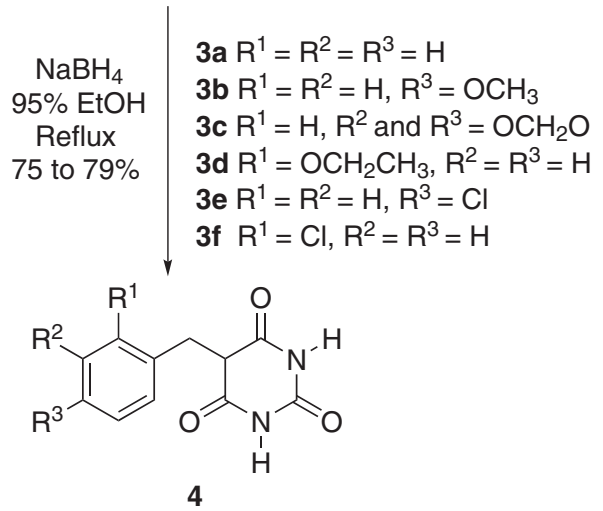

4a $R^{1}=R^{2}=R^{3}=H$

4b $R^{1}=R^{2}=H, R^{3}=\mathrm{OCH}_{3}$

4c $\mathrm{R}^{1}=\mathrm{H}, \mathrm{R}^{2}$ and $\mathrm{R}^{3}=\mathrm{OCH}_{2} \mathrm{O}$

4d $\mathrm{R}^{1}=\mathrm{OCH}_{2} \mathrm{CH}_{3}, \mathrm{R}^{2}=\mathrm{R}^{3}=\mathrm{H}$

4e $\mathrm{R}^{1}=\mathrm{R}^{2}=\mathrm{H}, \mathrm{R}^{3}=\mathrm{Cl}$

4f $\mathrm{R}^{1}=\mathrm{Cl}, \mathrm{R}^{2}=\mathrm{R}^{3}=\mathrm{H}$

Scheme 1. Synthetic sequence for the preparation of 5-chloro-benzobarbiturates.

accomplished using a very simple and efficient three step methodology, as shown in Scheme 1.

The Knovenagel condensation of benzaldehydes (1) with barbituric acid (2) was very simple, being accomplished by mixing the reagents in ethanol and water at $60{ }^{\circ} \mathrm{C}$ without the use of bases, affording the respective benzylidenebarbituric acids (3) in yields from 93 to $99 \%$. The benzylidenebarbiturates are characterized by a very polarized carbon-carbon double bond (C5-C7), ${ }^{10,19}$ which leads to chemical shifts from 111.7 to $119.80 \mathrm{ppm}$ for C5 and 147.2 to $154.5 \mathrm{ppm}$ for $\mathrm{C} 7$, and a singlet signal between 8.22 and $8.49 \mathrm{ppm}$ for $\mathrm{H} 7$. The polarization of this double bond facilitates its selective reduction, which can be accomplished using $\mathrm{Zn}$ in acetic acid ${ }^{20}$ or sodium borohydride in $95 \%$ ethanol at room temperature. ${ }^{21}$ For the reduction process in this work we used sodium borohydride, affording the reduced products (4) in yields varying from 75 to $79 \%$. The confirmation of the reduction was accomplished by analysis of the NMR spectra, showing the $\mathrm{sp}^{2}$ to $\mathrm{sp}^{3}$ hybridization change for $\mathrm{C} 5$ and $\mathrm{C} 7$, the signal of $\mathrm{H} 7$ as a doublet ( $2 \mathrm{H}, \delta 3.17$ to 3.51$)$ and of $\mathrm{H} 5$ as a triplet $(1 \mathrm{H}, \delta 3.77$ to 4.00$)$ in the reduced products. Finally, the chlorination was carried out by treatment of the reduced products with trichloro-isocyanuric acid (5) in acetone at room temperature. The use of trichloro-isocyanuric acid was motivated by its very low price, since it is a very cheap material used for treatment of water in swimming pools, and by its reported use as a very effective chlorinating ${ }^{22-24}$ and oxidizing compound. ${ }^{25}$ This chlorination reaction was carried out at room temperature with acetone as solvent, and the use of reflux conditions gives the same results with a better yield. In all cases the precipitated isocyanuric acid was filtered after completion of the reaction and the acetone solution mixed with water and extracted with ethyl acetate. After drying the solution and evaporating the solvent, the final products were purified by recrystallization in methanol or by filtration with silica gel. As expected, it was found that all the benzyl barbituric acids suffered chlorination at the 5 position of the pyrimidine ring, but it was also observed that compounds containing activated aromatic rings were chlorinated at the most reactive position of the aromatic ring. When this chlorination reaction was carried out at low temperatures $\left(0\right.$ to $\left.5{ }^{\circ} \mathrm{C}\right)$ it was observed that the reaction did not occur or that it afforded the same dichlorinated products obtained at room temperature, but at lower yields. On the other hand, compounds without electron-donating substituents, like 5-benzylbarbituric acid, or with electron withdrawing groups, like 2- or 4-chlorobenzylbarbituric acid, were not chlorinated at the aromatic ring. In all cases, the chlorination reaction was accomplished in yields varying from 72 to $94 \%$, leading to preparation of the final products (6) at overall yields of 53 to $70 \%$. 
All the final compounds were fully characterized using ${ }^{1} \mathrm{H}$ and ${ }^{13} \mathrm{C}$ NMR, infrared spectroscopy and mass spectrometry (see the Supplementary Information, SI).

The comparison of the ${ }^{13} \mathrm{C}$ NMR chemical shifts for all products indicated that the $\mathrm{C} 5$ carbon of 5-chloro-5benzylbarbituric acids, which does not have conjugation with the aromatic ring, has its chemical shift clearly affected by the position of the substituents at the aromatic ring. It is observed that compounds that have substituents at the ortho position display C5 chemical shifts above $64 \mathrm{ppm}$ while compounds with substitutions only at the meta and para positions have C5 chemical shifts between 61.8 and $61.9 \mathrm{ppm}$. Since there is not a normal direct interaction between the aromatic ring and the chlorinated $\mathrm{sp}^{3}$ carbon (C5), to understand this observation we carried a molecular modeling study of these compounds using the B3LYP method ${ }^{26,27}$ with the 6-311G(d) basis set. The conformational analysis of the compounds indicated two potential conformations for each compound, as the example shown in Figure 1 for compounds $\mathbf{6 b}$ and $\mathbf{6 d}$. For compound $\mathbf{6 b}$, which does not have a subtituent at the ortho position, the most stable conformation corresponds to Figure 1a, where the aromatic and the pyrimidine rings are closer to each other (dihedral angle $\mathrm{Cj}-\mathrm{C} 5-\mathrm{C} 7-\mathrm{C} 8$ of $-163.92^{\circ}$ ). The second most stable conformation displays the C5 chlorine atom closer to the aromatic ring $(3.146 \AA$ distance of the $\mathrm{Cl}$ of $\mathrm{C} 5$ to $\mathrm{C} 8$ and a dihedral angle $\mathrm{Cl}-\mathrm{C} 5-\mathrm{C} 7-\mathrm{C} 8$ of $37.89^{\circ}$ ) (Figure $1 \mathrm{~b}$ ). On the other hand, for compound 6d, which has an ortho-ethoxy group, the two lowest energy conformations (Figures 1c and 1d) do not possess interaction between the $\mathrm{Cl}$ of $\mathrm{C} 5$ and the aromatic ring, possessing Cl-C5-C7-C8 dihedral angles of $142.11^{\circ}$ and $66.32^{\circ}$.

For all the compounds, the energy difference between the two most stable conformers is close to $4 \mathrm{kcal} \mathrm{mol}^{-1}$, indicating that both conformations contribute significantly to the molecular geometry. Also, for compounds without substitution at the ortho position of the aromatic ring, the $\mathrm{C} 5$ chlorine atom of the second conformer is located at a distance between 3.135 and $3.150 \AA$ from the aromatic carbon $\mathrm{C} 8$, indicating that this chlorine atom can interact, via molecular orbitals, with the aromatic ring. These calculations explain the effect of substitution at the aromatic ring on the chemical shift of $\mathrm{C} 5$, because the presence of groups at the ortho position leads to conformations that decrease the possible interaction between the aromatic and the pyrimidine rings and, specifically, between the C5 chlorine atom and the aromatic ring via molecular orbitals.

In order to test the tranquilizing activity of the products there were carried out tests on a rota rod with mice. ${ }^{28}$

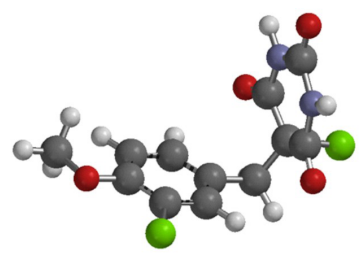

a

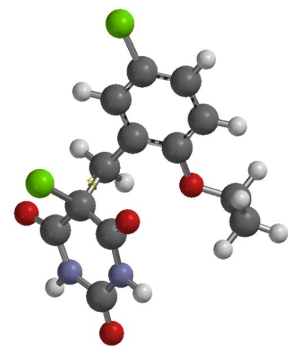

C

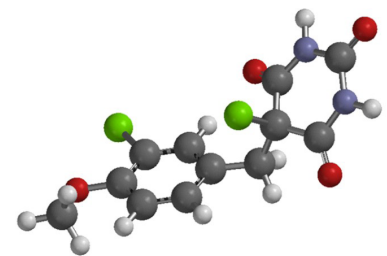

b

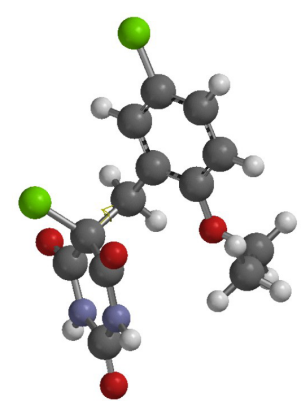

d
Figure 1. The two conformers of compounds $6 \mathbf{b}(\mathrm{a}$ and $\mathrm{b})$ and $\mathbf{6 d}(\mathrm{c}$ and d) calculated with B3LYPP 6-311G(d), where conformers a and c are the most stable for each compound.

These tests were not performed with compounds $\mathbf{6 a}$ and 6e because they could not be dissolved in a mixture of $0.5 \%$ dimethylsulfoxide (DMSO) in water. All the other compounds were tested with $10 \mathrm{mg} \mathrm{kg}^{-1}$ doses in mice. When mice were treated only with the vehicle solution (phosphate buffer in water with $0.5 \%$ DMSO) they fell $12.0 \pm 2.0$ times in a period of $10 \mathrm{~min}$. However, when they were treated with a $10 \mathrm{mg} \mathrm{kg}^{-1}$ dose of the compounds under the same conditions with a reference drug (barbituric acid), the number of falls from the rota rod increased significantly $(18.9 \pm 3.2)$. The results obtained with the final products at the same conditions are shown in Figure 2. The oral administration of $\mathbf{6 b}$ and $\mathbf{6 c}$ significantly increased the time necessary for the first fall of mice, while $\mathbf{6 d}$ and 6f decreased very significantly that time (Figure 2A). In parallel it was also observed that only $\mathbf{6 d}$ and $\mathbf{6} \mathbf{6}$ increased the total number of falls in the rota rod during $10 \mathrm{~min}$ (Figure 2B). Interestingly, 6d drastically reduced the time for the first fall, leading concomitantly to the greatest increase in the number of falls indicating that this is the compound with the greatest tranquilizing activity with no significant sedative effects.

The obtained data clearly indicate that the most active compounds are those with substituents at the ortho position, where $\mathbf{6 d}$, which has the bulkiest substituent at C9, is the most active one. On the other hand, compound $\mathbf{6 b}$, which 


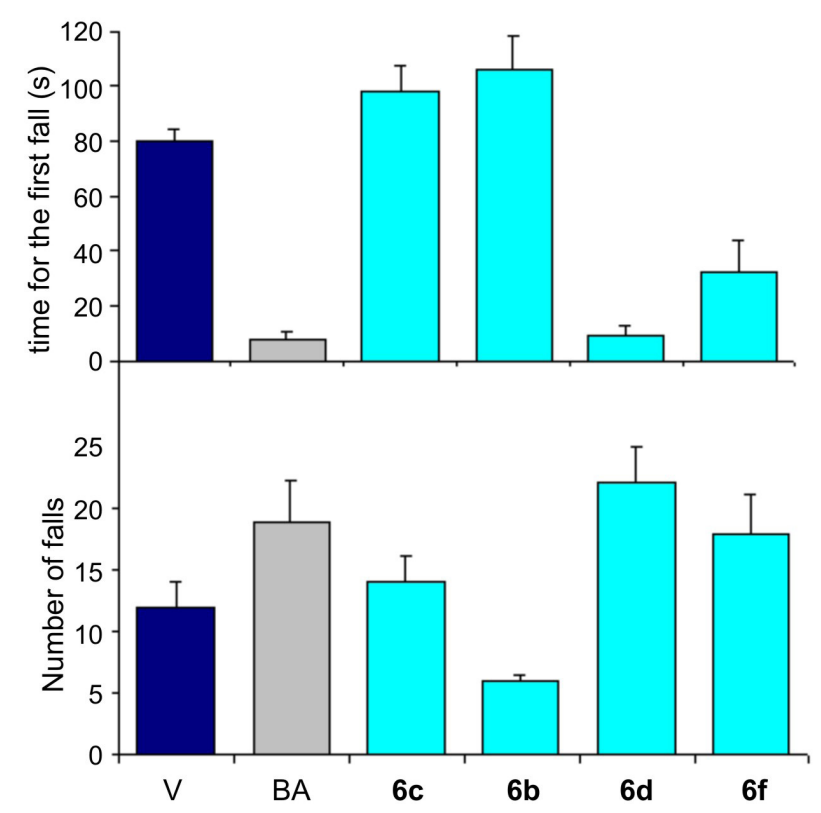

Figure 2. Results of the bioassays with mice using rota rod for compounds $\mathbf{6 b}, \mathbf{6 c}, \mathbf{6} \mathbf{d}$ and $\mathbf{6 f}$ ( $\mathrm{V}$ is vehicle: $0.5 \%$ solution of DMSO in water phosphate buffer and BA is barbituric acid).

does not have ortho substituents is the less active of all. These results are an indication that this new family of barbiturates has an interesting potential for their application as CNS active drugs.

\section{Conclusions}

We have developed a short (three steps), very efficient and cheap method for the synthesis of a new family of barbituric acid derivatives, which leads, without optimization of the process, to overall yields from 53 to $70 \%$. These compounds have shown central nervous system inhibitory activity in mice, with an indication that the presence of substituents at the ortho position of the aromatic ring is important for the improvement of their efficiency. This proposition is sustained by three experimental results. First, the tested compound with the bulkiest substitution at $\mathrm{C} 9(\mathbf{6 d})$ leads to the shortest time period (10 s) for the first fall and the greatest number of falls in $10 \mathrm{~min}$ (22) in the rota rod test with mice, being more effective than the reference compound. Second, the compounds with a chlorine atom at the ortho position (6c and $\mathbf{6 f}$ ) are also active, but with a lower efficiency compared with $\mathbf{6 d}$. Finally, it was observed that the less active product is the one without substitution at $\mathrm{C} 9$ or $\mathrm{C} 13$ (6b). A molecular modeling study of these compounds indicate that the presence of ortho substitution at the aromatic ring leads to changes on the molecular conformation, which may be responsible for the changes in CSN inhibitory activity.
We are now working on the design and synthesis of new members of this family of new barbiturates based on the discussed results.

\section{Experimental}

\section{Reagents}

The reagents (barbituric acid, $p$-anisaldehyde, piperonal, benzaldehyde, $o$-ethoxibenzaldehyde, $o$-chlorobenzaldehyde, $p$-chlorobenzaldehyde, anhydrous potassion bromide and sodium borohydride were acquired from Sigma-Aldrich. Commercial trichloroisocyanuric acid used for swimming pool treatment was used for the chlorination reactions. The solvents used such as, ethanol, ethyl acetate and acetone, were bought from Vetec and used after distillation.

\section{Equipments}

All the melting points were determined in a Fisher-Johns melting point apparatus using an uncalibrated thermometer. Thin layer chromatography was carried out using Merck $0.2 \mathrm{~mm}$ silica gel $60 \mathrm{~F}_{254}$ aluminum chromatographic plates. Column chromatography was performed using Vetec 40-63 $\mu \mathrm{m}$ (230-240 mesh) silica gel. The mass spectra were recorded using an Agilent model 6890N CG MS apparatus. Infrared spectra were determined using $\mathrm{KBr}$ pellets with a Shimadzu IR-470 spectrometer. The NMR data were collected using a Varian UNITY-300 NMR spectrometer ( ${ }^{1} \mathrm{H} \mathrm{NMR}$ at $300 \mathrm{MHz}$ and ${ }^{13} \mathrm{CNMR}$ at $75 \mathrm{MHz}$ ) with $5 \mathrm{~mm}$ sample tubes, TMS as internal reference and DMSO- $d_{6}$ (CIL) $98.8 \%$ as solvent.

\section{Synthesis}

General procedure for the preparation of the benzylidene barbituric acids $3 \boldsymbol{a}-\boldsymbol{f}$

$1.28 \mathrm{~g}(10 \mathrm{mmol})$ of barbituric acid was dissolved in $50 \mathrm{~mL}$ of water under heating in a $200 \mathrm{~mL}$ beaker, followed by the addition of a solution of $12 \mathrm{mmol}$ of the aldehyde in $10 \mathrm{~mL}$ of $95 \%$ ethanol. After few min of heating there was observed the formation of a precipitate and the reaction mixture was kept under stirring without heating for $30 \mathrm{~min}$. The solid was filtered, washed with water and ethyl acetate and recrystallized from methanol.

\section{5-Benzylidene-pyrimidine-2,4,6(1H,3H)-trione $3 a$}

The clear yellow precipitate was obtained in $98 \%$ yield; $\mathrm{mp} 274-276^{\circ} \mathrm{C}$. IR (KBr) $v_{\max } / \mathrm{cm}^{-1} 3216,3068,2848,1752$, 1681, 1561, 1450, 1405, 1298, 1199, 870, 804, 686, 528 
and 429. ${ }^{1} \mathrm{H}$ NMR (DMSO- $\left.d_{6}\right) \delta 11.38(1 \mathrm{H}, \mathrm{s}), 11.27(1 \mathrm{H}$, s), $8.28(1 \mathrm{H}, \mathrm{s}), 8.08(2 \mathrm{H}, \mathrm{d}, J 7.0 \mathrm{~Hz})$ and $7.48(3 \mathrm{H}, \mathrm{t}, J$ $5.0 \mathrm{~Hz}) .{ }^{13} \mathrm{C}$ NMR (DMSO- $\left.d_{6}\right) \delta 163.3,161.5,154.6,150.1$, 133.0, 132.6, 132.3, 128.2 and 119.1.

\section{5-(4-Methoxibenzylidene)-pyrimidine-2,4,6(1H,3H)-trione} $3 b$

The intense yellow precipitate was obtained in $94.8 \%$ yield; $\mathrm{mp} 265-268^{\circ} \mathrm{C}$. IR $(\mathrm{KBr}) v_{\max } / \mathrm{cm}^{-1} 3207,3083,2832$, 1735, 1680, 1555, 1680, 1298, 1252, 1166, 1028, 844, 798, 745 and 512. ${ }^{1} \mathrm{H}$ NMR (DMSO- $\left.d_{6}\right) \delta 11.28(1 \mathrm{H}, \mathrm{s}), 11.20$ $(1 \mathrm{H}, \mathrm{s}), 8.37(2 \mathrm{H}, \mathrm{d}, J 6.0 \mathrm{~Hz}), 7.07(2 \mathrm{H}, \mathrm{d}, J 6.0 \mathrm{~Hz})$ and $3.87(3 \mathrm{H}, \mathrm{s}) .{ }^{13} \mathrm{C}$ NMR (DMSO- $\left.d_{6}\right) \delta 163.9,163.4,162.1$, $154.9,150.5,137.4,125.1,115.5,113.9$ and 55.7.

\section{5-(3,4-Methyledioxibenzylidene)-pyrimidine- 2,4,6(1H,3H)-trione $3 \mathrm{c}$}

The yellow solid was obtained in $92.6 \%$ yield; $\mathrm{mp}$ 265-266 ${ }^{\circ} \mathrm{C}$. IR (KBr) $v_{\text {max }} / \mathrm{cm}^{-1} 3230,3093,2823,1735$, 1670, 1550, 1454, 1250, 1032, 806, 610 and 501. ${ }^{1} \mathrm{H}$ NMR $\left(\right.$ DMSO- $\left.d_{6}\right) \delta 11.32(1 \mathrm{H}, \mathrm{s}), 11.20(1 \mathrm{H}, \mathrm{s}), 8.25(1 \mathrm{H}, \mathrm{s}), 8.20$ $(1 \mathrm{H}, \mathrm{s}), 7.72(1 \mathrm{H}, \mathrm{d}, J 5.6 \mathrm{~Hz}), 7.05(1 \mathrm{H}, \mathrm{d}, J 6.2 \mathrm{~Hz})$ and $6.18(2 \mathrm{H}, \mathrm{s}) .{ }^{13} \mathrm{C}$ NMR (DMSO- $\left.d_{6}\right) \delta 163.8,162.2,154.9$, 151.8, 147.3, $133.6126 .7,115.2,112.4,108.3$ and 102.3.

\section{5-(2-Ethoxibenzylidene)-pyrimidine-2,4,6(1H,3H)-trione $3 d$}

The intense yellow solid was obtained in $92.9 \%$ yield; $\mathrm{mp} 260-262^{\circ} \mathrm{C}$ IR (KBr) $v_{\max } / \mathrm{cm}^{-1} 3207,3083,2832,1739$, 1681, 1552, 1430, 1377, 1304, 1252, 1173, 1127, 1041, 943, 739, 574 and 535. ${ }^{1} \mathrm{H}$ NMR (DMSO- $\left.d_{6}\right) \delta 11.33(1 \mathrm{H}$, s), $11.15(1 \mathrm{H}, \mathrm{s}), 8.49(1 \mathrm{H}, \mathrm{s}), 7.96(1 \mathrm{H}, \mathrm{d}, J 4.5 \mathrm{~Hz}), 7.48$ $(1 \mathrm{H}, \mathrm{t}, J 7.0 \mathrm{~Hz}), 7.09(1 \mathrm{H}, \mathrm{d}, J 5.8), 6.95(1 \mathrm{H}, \mathrm{t}, J 6.0)$, $4.13(2 \mathrm{H}, \mathrm{q}, J 4.5 \mathrm{~Hz}), 1.35(3 \mathrm{H}, \mathrm{t}, J 4.5 \mathrm{~Hz}) .{ }^{13} \mathrm{C} \mathrm{NMR}$ (DMSO- $d_{6}$ ) $\delta 163.4,161.4,158.3,150.2,150.0,134.0$, $132.5,121.6,119.3,118.6,111.8,64.0$ and 14.5.

\section{5-(4-Chlorobenzylidene)-pyrimidine-2,4,6(1H,3H)-trione $3 e$}

The yellow solid was obtained in 95\% yield; mp 296$298^{\circ} \mathrm{C}$ IR (KBr) v $v_{\max } / \mathrm{cm}^{-1} 3012,2350,1703,1673,1575$, 1490, 1413, 1338, 1223, 1091, 1016, 975, 718 and 681. ${ }^{1} \mathrm{H}$ NMR (DMSO- $\left.d_{6}\right) \delta 11.41(1 \mathrm{H}, \mathrm{s}), 11.30(1 \mathrm{H}, \mathrm{s}), 8.22$ $(1 \mathrm{H}, \mathrm{s}), 8.08(2 \mathrm{H}, \mathrm{d}, J 8.7 \mathrm{~Hz}), 7.53(2 \mathrm{H}, \mathrm{d}, J 8.7 \mathrm{~Hz}) .{ }^{13} \mathrm{C}$ NMR (DMSO- $d_{6}$ ) $\delta$ 163.2, 161.6, 152.9, 150.1, 137.0, 135.0, 131.6, 128.1 and 119.7.

\section{5-(2-Chlorophenyl)-methylene-pyrimidine-2,4,6(1H,3H)- trione $3 f$}

The yellow solid was obtained in $96.5 \%$ yield; $\mathrm{mp}$ 242-243 ${ }^{\circ} \mathrm{C}$ IR (KBr) $v_{\max } / \mathrm{cm}^{-1} 3212,3081,2836,1759$,
1692, 1601, 1423, 1370, 1311, 1219, 1061, 943, 798, 758 and 532. ${ }^{1} \mathrm{H}$ NMR (DMSO- $\left.d_{6}\right) \delta 11.49(1 \mathrm{H}, \mathrm{s}), 11.27(1 \mathrm{H}$, s), $8.29(1 \mathrm{H}, \mathrm{s}), 7.73(1 \mathrm{H}, \mathrm{d}, J 5.5 \mathrm{~Hz}), 7.53(1 \mathrm{H}, \mathrm{t}, J 5.0$ $\mathrm{Hz}), 7.46(1 \mathrm{H}, \mathrm{t}, J 5.8 \mathrm{~Hz})$ and $7.35(1 \mathrm{H}, \mathrm{d}, J 5.8 \mathrm{~Hz}) .{ }^{13} \mathrm{C}$ NMR (DMSO- $d_{6}$ ) $\delta 162.7,160.4,150.3,149.8,133.3$, $132.3,130.0,132.0,128.9,126.4$ and 121.8.

General procedure for the preparation of the 5-benzybarbituric acids $\mathbf{4 a - f}$

In a $250 \mathrm{~mL}$ round bottom flask there were dissolved $2.5 \mathrm{~g}$ of the benzylidene barbituric acid in $150 \mathrm{~mL}$ of $95 \%$ ethanol. The stirred solution was treated with small consecutive portions of $\mathrm{NaBH}_{4}$ until the formation of hydrogen gas was not observed. Then the mixture was refluxed for $30 \mathrm{~min}$. After cooling to room temperature the reaction mixture was acidified to $\mathrm{pH} 2$ using $6 \mathrm{~mol} \mathrm{~L}^{-1}$ hydrochloric acid $(\mathrm{HCl})$. Then the ethanol was evaporated under vacuum and the residue dissolved in water and extracted three times with ethyl acetate. The organic extract was treated with anhydrous sodium sulfate, filtered and the solvent evaporated under vacuum. The solid product was recrystallized from an appropriate solvent.

\section{5-Benzylbarbituric acid $\mathbf{4 a}$}

The white solid was recrystallized from acetic acid, leading to $75.4 \%$ yield; mp $223-226{ }^{\circ} \mathrm{C}$. IR (KBR) $v_{\max } / \mathrm{cm}^{-1} 3232,3097,2850,1716,1495,1442,1370,1206$, 1054, 850, 798, 739, 699, 640, 508 and 495. ${ }^{1} \mathrm{H}$ NMR $\left(\mathrm{DMSO}_{6}\right) \delta 11.17(2 \mathrm{H}, \mathrm{s}), 7.23(3 \mathrm{H}, \mathrm{m}, J 4.0 \mathrm{~Hz}), 7.09$ $(2 \mathrm{H}, \mathrm{d}, J 3.8 \mathrm{~Hz}), 3.90(1 \mathrm{H}, \mathrm{t}, J 5.0 \mathrm{~Hz})$ and $3.25(3 \mathrm{H}, \mathrm{d}, J$ $5.5 \mathrm{~Hz}$ ). ${ }^{13} \mathrm{C}$ NMR (DMSO- $d_{6}$ ) $\delta 169.9,150.5,137.4,128.9$, 128.3, 126.7 and 49.3 .

\section{5-(4-Methoxibenzyl)-barbituric acid $\mathbf{4 b}$}

The yellow solid was recrystallized from methanol, leading to $76.9 \%$ yield; $\mathrm{mp} 204-207{ }^{\circ} \mathrm{C}$. IR (KBR) $v_{\max } / \mathrm{cm}^{-1} 3230,2967,2654,2575,1751,1574,1515,1690$, $1304,1252,1179,1113,1041,837,798,751$ and $581 .{ }^{~}{ }^{\mathrm{H}}$ NMR (DMSO- $\left.d_{6}\right) \delta 11.92(2 \mathrm{H}, \mathrm{s}), 7.13(2 \mathrm{H}, \mathrm{d}, J 3.4 \mathrm{~Hz})$, $7.07(2 \mathrm{H}, \mathrm{d}, J 3.6 \mathrm{~Hz}), 4.00(1 \mathrm{H}, \mathrm{t}, J 4.0 \mathrm{~Hz}), 3.82(3 \mathrm{H}, \mathrm{s})$ and $3.51(2 \mathrm{H}, \mathrm{d}, J 3.8 \mathrm{~Hz}) .{ }^{13} \mathrm{C}$ NMR (DMSO- $\left.d_{6}\right) \delta 167.1$, $154.8,149.2,132.3,131.0,113.4,62.5,56.8$ and 42.4 .

\section{5-(3,4-Methylenedioxibenzyl)-barbituric acid $\mathbf{4 c}$}

The yellow solid was recrystallized form methanol, leading to $79.5 \%$ yield; $\mathrm{mp} 255-259{ }^{\circ} \mathrm{C}$. IR ( $\left.\mathrm{KBr}\right)$ $v_{\max } / \mathrm{cm}^{-1} 3417,3222,3101,2846,1708,1502,1442,1351$, 1317, 1242, 1100, 1041, 923, 811, 626 and 501. ${ }^{1} \mathrm{H}$ NMR $\left(\right.$ DMSO- $\left.d_{6}\right) \delta 11.19(2 \mathrm{H}, \mathrm{s}), 6.78(1 \mathrm{H}, \mathrm{d}, J 7.5 \mathrm{~Hz}), 6.60$ $(1 \mathrm{H}, \mathrm{s}), 6.55(1 \mathrm{H}, \mathrm{d}, J 7.5 \mathrm{~Hz}), 5.96(2 \mathrm{H}, \mathrm{s}), 3.82(1 \mathrm{H}, \mathrm{t}, J$ $4.5 \mathrm{~Hz})$ and $3.17(2 \mathrm{H}, \mathrm{d}, J 4.5 \mathrm{~Hz}) .{ }^{13} \mathrm{C}$ NMR (DMSO- $\left.d_{6}\right)$ 
$\delta$ 170.6, 151.3, 147.7, 146.7, 131.5, 122.7, 110.0, 108.8, 101.5, 50.3 and 33.9.

\section{5-(2-Ethoxibenzyl)-barbituric acid $\mathbf{4 d}$}

The yellow solid was recrystallized from methanol, leading to $75.0 \%$ yield; $\mathrm{mp} 224-226^{\circ} \mathrm{C}$. IR $(\mathrm{KBr}) v_{\max } / \mathrm{cm}^{-1}$ $3205,3077,2875,1772,1699,1594,1495,1450,1383$, 1324, 1298, 1246, 1153, 1113, 1148, 929, 857, 745 and 501. ${ }^{1} \mathrm{H}$ NMR (DMSO- $\left.d_{6}\right) \delta 11.05(2 \mathrm{H}, \mathrm{s}), 7.15(1 \mathrm{H}, \mathrm{d}$, $J 5.0 \mathrm{~Hz}), 7.00(1 \mathrm{H}, \mathrm{t}, J 4.8 \mathrm{~Hz}), 6.90(1 \mathrm{H}, \mathrm{d}, J 5.5 \mathrm{~Hz})$, $6.80(1 \mathrm{H}, \mathrm{t}, J 5.0 \mathrm{~Hz}), 3.97(2 \mathrm{H}, \mathrm{q}, J 4.9 \mathrm{~Hz}), 3.77(1 \mathrm{H}$, $\mathrm{t}, J 5.8 \mathrm{~Hz}), 3.19(2 \mathrm{H}, \mathrm{d}, J 5.8 \mathrm{~Hz})$ and $1.32(3 \mathrm{H}, \mathrm{t}, J 4.5$ Hz). ${ }^{13} \mathrm{C}$ NMR (DMSO- $d_{6}$ ) $\delta 169.9,156.5,150.9,130.2$, $127.9,125.4,126.0,119.8,111.2,63.1,48.1,29.3$ and 14.6.

\section{5-(4-Chlorobenzyl)-barbituric acid $\mathbf{4 e}$}

The white solid was recrystallized from ethanol $95 \%$ leading to $77 \%$ yield; $\mathrm{mp} 210-212{ }^{\circ} \mathrm{C}$. IR $(\mathrm{KBr}) v_{\max } / \mathrm{cm}^{-1}$ 3202, 2652, 1728, 1672, 1563, 1511, 1488, 1376, 1176, $1018,854,820,753$ and $679 .{ }^{~} \mathrm{H}$ NMR (DMSO- $d_{6}$ ) $\delta 11.20$ $(2 \mathrm{H}, \mathrm{s}), 7.32(2 \mathrm{H}, \mathrm{d}, J 8.1 \mathrm{~Hz}), 7.12(2 \mathrm{H}, \mathrm{d}, J 8.1 \mathrm{~Hz}), 3.95$ $(1 \mathrm{H}, \mathrm{t}), 3.23(2 \mathrm{H}, \mathrm{d}) .{ }^{13} \mathrm{C}$ NMR (DMSO- $\left.d_{6}\right) \delta 170.4,151.2$, 137.4, 131.5, 132.0, 128.9, 50.0 and 33.0.

\section{5-(2-Chlorobenzyl)-barbituric acid $\mathbf{4 f}$}

The white solid was recrystallized from ethanol 95\% leading to $75.7 \%$ yield; $\mathrm{mp} 223-227^{\circ} \mathrm{C}$. IR (KBR) $v_{\max } / \mathrm{cm}^{-1}$ 3212, 2818, 2515, 2266, 1699, 1193, 1085, 811, 745, 646, 541 and 449. ${ }^{1} \mathrm{H}$ NMR (DMSO- $\left.d_{6}\right) \delta 11.20(2 \mathrm{H}, \mathrm{s})$, $7.40(1 \mathrm{H}, \mathrm{d}, J 5.5 \mathrm{~Hz}), 7.23(2 \mathrm{H}, \mathrm{t}, J 4.5 \mathrm{~Hz}) ; 7.00(1 \mathrm{H}, \mathrm{d}$, $J 4.8 \mathrm{~Hz}), 4.00(1 \mathrm{H}, \mathrm{t}, J 6.5 \mathrm{~Hz})$ and $3.32(2 \mathrm{H}, \mathrm{t}, J 6.5 \mathrm{~Hz})$. ${ }^{13} \mathrm{C}$ NMR (DMSO- $d_{6}$ ) $\delta 169.8,151.1,136.0,133.4,130.8$, 129.3, 128.4, 127.1, 48.1 and 30.6.

General procedure for the chlorination of the benzylbarbituric acids with tricholroisocyanuric acid $\mathbf{6} \boldsymbol{a}-\boldsymbol{f}$

$3.2 \mathrm{mmol}$ of the reduced compounds were dissolved in $30 \mathrm{~mL}$ of acetone in a $50 \mathrm{~mL}$ round bottom flask. Then it was added $0.74 \mathrm{~g}(3.2 \mathrm{mmol})$ of trichloroisocyanuric acid and the reaction mixture was kept under reflux and stirring for $2.5 \mathrm{~h}$. The reaction mixture was then filtered to eliminate the excess of trichloroisocyanuric acid and the formed isocyanuric acid. Then, the acetone solution was mixed with cool water and extracted with ethyl acetate three times. The organic extracts were dried with anhydrous sodium sulfate for $1 \mathrm{~h}$, filtered and the solvent evaporated under vacuum. All the solid products were purified by recrystallization with methanol or by filtration with silica gel using the appropriate elution solvent. The ${ }^{1} \mathrm{H}$ and ${ }^{13} \mathrm{C}$ NMR data for these compounds are listed on Tables S1 and S2 (SI).

\section{5-Chloro-5-benzyl barbituric acid $\mathbf{6 a}$}

This compound was purified by filtration through a silica gel chromatographic column using ethyl acetate:hexane 4:6 as elution solvent, leading to the preparation of $0.74 \mathrm{~g}$ of 6a as a white solid in $93.7 \%$ yield (70\% overall yield); $\mathrm{mp}$ 184-185 ${ }^{\circ} \mathrm{C}$. IR (KBr) $v_{\max } / \mathrm{cm}^{-1} 3263,3122,1731,1502$, 1442, 1357, 1265, 1211, 1206, 1128, 1020, 850, 811, 698, 663, 614, 567 and 511.

\section{5-Chloro-5-(3-chloro-4-methoxibenzyl) barbituric acid $\mathbf{6} \boldsymbol{b}$}

This compound was purified by recrystallization in methanol followed by filtration on a silica gel column using ethyl acetate:hexane 3:7 as elution solvent, leading to preparation of $0.90 \mathrm{~g}$ of $\mathbf{6 b}(89.0 \%$ yield, $65 \%$ overall yield) as a clear yellow solid; mp $130-132{ }^{\circ} \mathrm{C}$. IR (KBr) $\mathrm{v}_{\max } / \mathrm{cm}^{-1} 3303,3237,2995,1771,1704,1602,1502$, 1430, 1390, 1357, 1258, 1206, 1068, 1022, 870, 791, 692, 581 and 495.

\section{5-Chloro-5-(6-chloro-3,5-methylenedioxibenzyl)-barbituric acid $6 c$}

This compound was purified by recrystallization in methanol followed by filtration on a silica gel column using ethyl acetate:hexane 2:8 as elution solvent, producing $0.86 \mathrm{~g}$ of $\mathbf{6 c}$ (82\% yield, $60 \%$ overall yield) as a clear yellow solid; mp $234-235^{\circ} \mathrm{C}$. IR (KBr) $v_{\max } / \mathrm{cm}^{-1} 3214,3114,3060$, 2910, 1718, 1765, 1481, 1502, 1403, 1357, 1238, 1199, $923,896,758,600$ and 501 .

\section{5-Chloro-5-(5-chloro-2-ethoxibenzyl)-barbituric acid $\mathbf{6 d}$}

This compound was purified by recrystallization in methanol followed by filtration on a silica gel column using ethyl acetate:hexane 3:7 as elution solvent, leading to preparation of $0.92 \mathrm{~g}$ ( $88 \%$ yield, $61 \%$ overall yield) of 6d as a white solid; mp 251-254 ${ }^{\circ} \mathrm{C}$. IR (KBR) $v_{\max } / \mathrm{cm}^{-1}$ 3415, 3205, 3095, 2943, 2863, 1759, 1732, 1700, 1587, 1494, 1397, 1253, 1137, 1047, 949, 857, 660, 587 and 493.

\section{5-Chloro-5-(4-chlorobenzyl)-barbituric acid $\mathbf{6 e}$}

This compound was purified by filtration on a silica gel column using ethyl acetate:hexane 3:7 as elution solvent, leading to preparation of $0.79 \mathrm{~g}$ (87\% yield, $53 \%$ overall yield) of 6e as a white solid; mp $188-189{ }^{\circ} \mathrm{C}$. IR (KBr) $v_{\text {max }} / \mathrm{cm}^{-1} 3229,3002,1730,1491,1423,1408,1354,1337$, 1311, 1273, 1192, 1092, 1015, 975, 819, 797, 681 and 664.

\section{5-Chloro-5-(2-chlorobenzyl)-barbituric acid $6 f$}

This compound was purified by filtration on a silica gel column using ethyl acetate:hexane 3:7 as elution solvent, leading to preparation of $0.79 \mathrm{~g}$ ( $87 \%$ yield, $61 \%$ overall yield) of $\mathbf{6 f}$ as a white solid; mp $202-204{ }^{\circ} \mathrm{C}$. IR (KBr) 
$v_{\max } / \mathrm{cm}^{-1} 3239,3095,2852,1727,1482,1430,1348,1344$, $1238,1186,1048,955,857,765,679,600$ and 495.

\section{Molecular modeling}

The preliminary molecular modeling calculations of the 5-chloro-5-benzylbarbituric acids were carried out with the Spartan06 package ${ }^{29}$ using the DFT method B3LYP and the basis set 6-311G(d).

\section{Bioassays}

Sample preparation for bioassays: Compounds $\mathbf{6 b}, \mathbf{6 c}$, $\mathbf{6 d}$ and $\mathbf{6 f}$ were dissolved in DMSO in order to prepare a stock solution at a concentration of $100 \mathrm{mg} \mathrm{mL}^{-1}$. In all experiments, the final concentration of DMSO did not exceed $0.5 \%$ in water at which this solvent had no effect per se. All substances were administered to mice by oral gavage at $10 \mathrm{mg} \mathrm{kg}^{-1}$.

\section{Animals}

All experiments were performed with male Swiss 44 mice (20-25 g) obtained from our own animal facility. Animals were maintained in a room with controlled temperature $\left(22 \pm 2{ }^{\circ} \mathrm{C}\right)$ for $12 \mathrm{~h} \mathrm{light/dark} \mathrm{cycle} \mathrm{with}$ free access to food and water. Animal care and research protocols were in accordance with the principles and guidelines adopted by the Brazilian College of Animal Experimentation (COBEA), approved by the Ethical Committee for Animal Research (Biomedical Science Institute/UFRJ), and received the number DFBCICB-015.

\section{Rota rod method}

Animals were placed individually in a revolving rod and those that demonstrated the ability to on the rod for at least $1 \mathrm{~min}$ were used for the test. The test compounds (at a $10 \mathrm{mg} \mathrm{kg}^{-1}$ dose) were administered p.o. (per os; by mouth) and $60 \mathrm{~min}$ before the mice were placed for $10 \mathrm{~min}$ in the rotating rod.

\section{Statistical analysis}

Experimental groups were composed by 5 to 7 animals. The results are presented as the mean \pm standard deviation (S.D.) of the number of falls during the test time $(10 \mathrm{~min})$ and the time (in s) necessary to the first fall. Statistical significance between groups was performed by the application of analysis of variance ANOVA followed by Bonferroni's test. $p$ values less than $0.05(p<0.01)$ were used as the significant level.

\section{Supplementary Information}

Supplementary information is available free of charge at http://jbcs.sbq.org.br, as PDF file.

\section{Acknowledgments}

We are grateful for the financial support and scholarships given to our research groups by the Brazilian financing agencies CNPq, CAPES, FAPERJ and the Ministry of Defense, as well as to the financial support from INBEBB (INCT-CNPq).

\section{References}

1. Holtkamp, M.; Meierkord, H.; Cell. Mol. Life Sci. 2007, 64, 2023.

2. Wagner, B. K. J.; O'Hara, D. A.; Clin. Pharmacokinet. 1997, $33,426$.

3. Anand, K. J. S.; Hall, R. W.; Arch. Dis. Child Fetal Neonatal Ed. 2006, 91, F448; Macdonald, R. L.; Kelly, K. M.; Epilepsia 1995, 36, S2.

4. Ffrench-Mullen, J. M. H.; Baker, J. L.; Rogawski, A. A.; J. Neurosci. 1993, 13, 3211.

5. Barry, H.; Appel, J.; Psycopharmacology 2009, 203, 193.

6. Johns, M. W.; Drugs 1975, 9448.

7. Rossetti, A. O.; Epilepsia 2007, 48, 52.

8. Wunderlich, H.; Goldhahn, H.; Patent DD31756-A; DE1212541-A 1961; Wunderlich, H.; Patent DD44123-A 1965.

9. Bednar, R.; Haslinger, E.; Herzig, U.; Polansky,O. E.; Wolschnn, P.; Monatsh. Chem. 1976, 107, 1115.

10. Figueroa-Villar, J. D.; Carneiro, C. L.; Cruz, E. R.; Heterocycles 1992, 34, 891.

11. Ashnagar, A.; Naseri, N. G.; Sheeri, B.; Chin. J. Chem. 2007, 25,382 .

12. Alcerreca, G.; Sanabria, R.; Miranda, R.; Arroyo, G.; Tamariz, J.; Delgado, F.; Synth. Commun. 2000, 30, 1295.

13. Seeliger, F.; Berger, S. T. A.; J. Org. Chem. 2007, 72, 9170.

14. Figueroa-Villar, J. D.; Cruz, E. R.; Tetrahedron 1993, 49, 2855.

15. Figueroa-Villar, J. D.; Santos, N. L.; Cruz, E. R.; Synth. Commun. 1992, 22, 1159.

16. Ruble, J. C.; Hurd, A. R.; Johnson, T. A.; Sherry, D. A.; Barbachyn, M. R.; Toogood, P. L.; Bundy, G. L.; Graber, D. R.; Kamilar, G. M.; J. Am. Chem. Soc. 2009, 131, 3991.

17. Shul'ts, E. E.; Andreev, G. N.; Shakirov, M. M.; Komarova, N. I.; Bagryanskaya, I. Yu.; Gatilov, Yu. V.; Tolstikov, G. A.; Russ. J. Org. Chem. 2009, 45, 87.

18. Haldar, M. K.; Scott, M. D.; Sule, N.; Srivastava, D. K.; Mallik, S.; Bioorg. Med. Chem. Lett. 2008, 18, 2373.

19. Stefan, F. S.; Berger, T. A.; Remennikov, G. Y.; Polborn, K.; Mayr, H.; J. Org. Chem. 2007, 72, 9170. 
20. Jursic, B. S.; Stevens, E. D.; Tetrahedron Lett. 2003, 44, 2203.

21. Kadin, S. B.; J. Org. Chem. 1966, 31, 620.

22. Hiegels, G. A.; Peyton, K. B.; Synth. Commun. 1985, 15, 385.

23. Mendonça, G. F.; Mattos, M. C. S.; Quim. Nova 2008, 31, 798.

24. Mendonça, G. F.; Sindra, H.; Almeida, L. S.; Esteves, P.; Mattos, M. C. S.; Tetrahedron Lett. 2009, 50, 473.

25. Motta, M. A.; Figueroa-Villar, J. D.; Nucleosides, Nucleotides Nucleic Acids 2000, 19, 1005.

26. Becke, A. D. J.; J. Chem. Phys. 1993, 98, 5648.

27. Lee, C. T.; Yang, W. T.; Parr, R. G.; Phys. Rev. B 1988, 37, 785.

28. Galeotti, N.; Vivole, E.; Bilia, A. R.; Vincieri, F. F.; Ghelardini, C.; Biochem. Pharmacol. 2010, 79, 1327.

29. Shao, Y.; Molnar, L. F.; Jung, Y.; Kussmann, J.; Ochsenfeld, C.; Brown, S. T.; Gilbert, A. T. B.; Slipchenko, L. V.; Levchenko, S. V.; O’Neill, D. P.; DiStasio Jr., R. A.; Lochan, R. C.; Wang, T.; Beran, G. J. O.; Besley, N. A.; Herbert, J. M.; Lin, C. Y.; Van
Voorhis, T.; Chien, S. H.; Sodt, A.; Steele, R. P.; Rassolov, V. A.; Maslen, P. E.; Korambath, P. P.; Adamson, R. D.; Austin, B.; Baker, J.; Byrd, E. F. C.; Dachsel, H.; Doerksen, R. J.; Dreuw, A.; Dunietz, B. D.; Dutoi, A. D.; Furlani, T. R.; Gwaltney, S. R.; Heyden, A.; Hirata, S.; Hsu, C. P.; Kedziora, G.; Khalliulin, R. Z.; Klunzinger, P.; Lee, A. M.; Lee, M. S.; Liang, W. Z.; Lotan, I.; Nair, N.; Peters, B.; Proynov, E. I.; Pieniazek, P. A.; Rhee, Y. M.; Ritchie, J.; Rosta, E.; Sherrill, C. D.; Simmonett, A. C.; Subotnik, J. E.; Woodcock III, H. L.; Zhang, W.; Bell, A. T.; Chakraborty, A. K.; Chipman, D. M.; Keil, F. J.; Warshel, A.; Hehre, W. J.; Schaefer, H. F.; Kong, J.; Krylov, A. I.; Gill, P. M. W.; Head-Gordon, M.; Phys. Chem. Chem. Phys. 2006, 8, 3172 .

Submitted: July 5, 2010 Published online: October 5, 2010 


\section{Synthesis and In Vivo Evaluation of 5-Chloro-5-benzobarbiturates as New Central Nervous System Depressants}

\section{A. A. Vieira, N. M. Gomes, M. E. Matheus, P. D. Fernandes and José D. Figueroa-Villar*}

${ }^{a}$ Medicinal Chemistry Group, Department of Chemistry, Military Institute of Engineering,

Praça General Tibúrcio 80, 22290-270, Rio de Janeiro-RJ, Brazil.

${ }^{b}$ Laboratório de Farmacologia da Inflamação e do Óxido Nítrico, Instituto de Ciências Biomédicas, Universidade Federal do Rio de Janeiro, Av. Carlos Chagas Filho 373, CCS, Bloco J, Rio de Janeiro-RJ, Brazil

Collection of ${ }^{1} \mathrm{H}$ NMR, ${ }^{13} \mathrm{C}$ NMR and IR spectra of compounds $6 \mathbf{a}$ to $\mathbf{6 f}$, and Tables S1 and S2 with the assignment of the ${ }^{1} \mathrm{H}$ and ${ }^{13} \mathrm{C}$ NMR signals. respectivelv.

\section{Compound 6a}
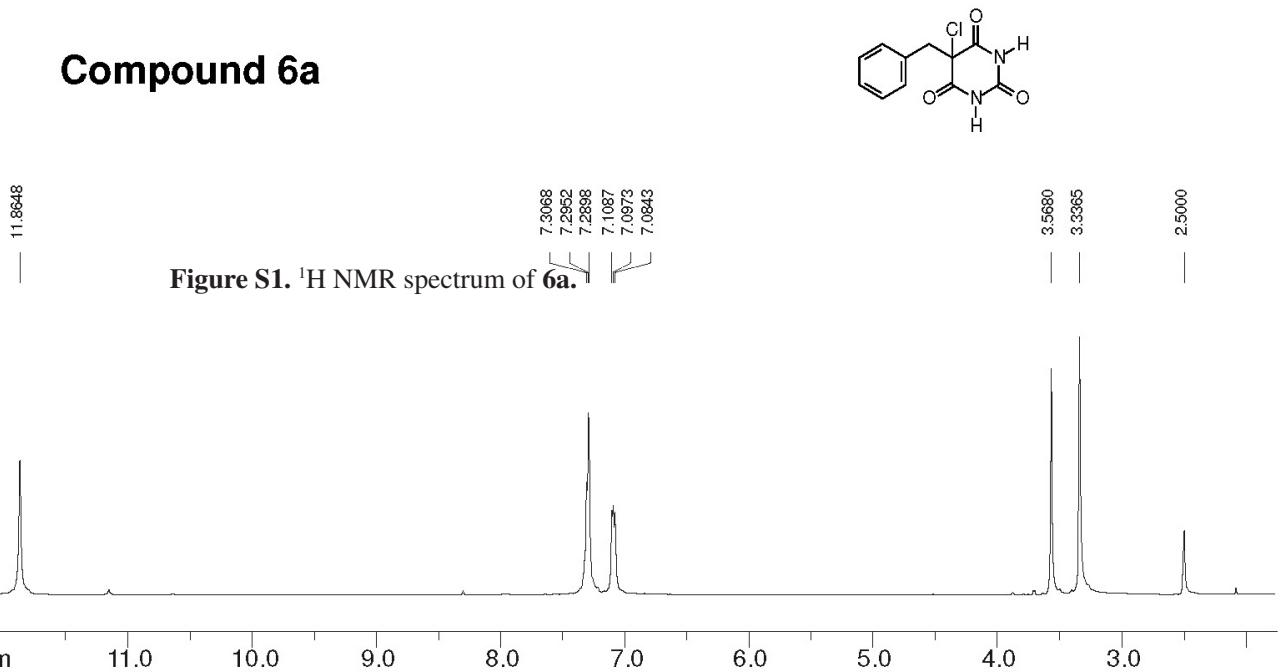

Figure S1. ${ }^{1} \mathrm{H}$ NMR spectrum of $\mathbf{6 a}$.
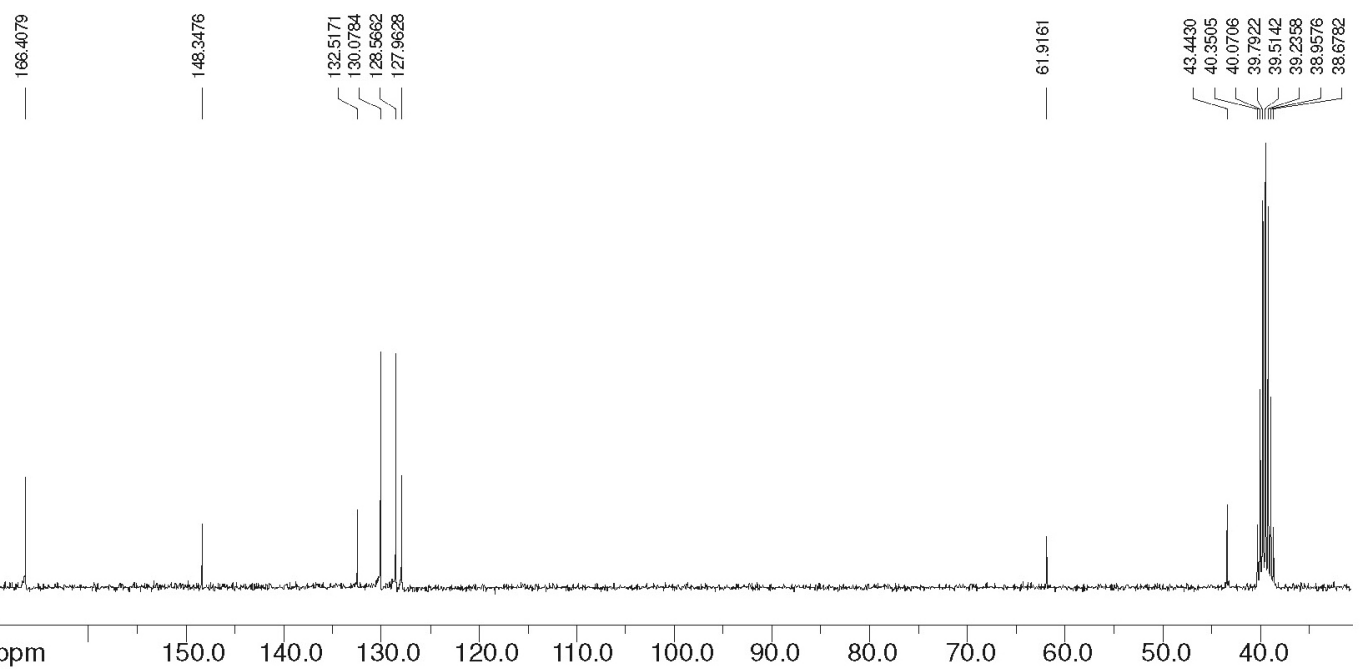

Figure S2. ${ }^{13} \mathrm{C}$ NMR spectrum of $\mathbf{6 a}$. 


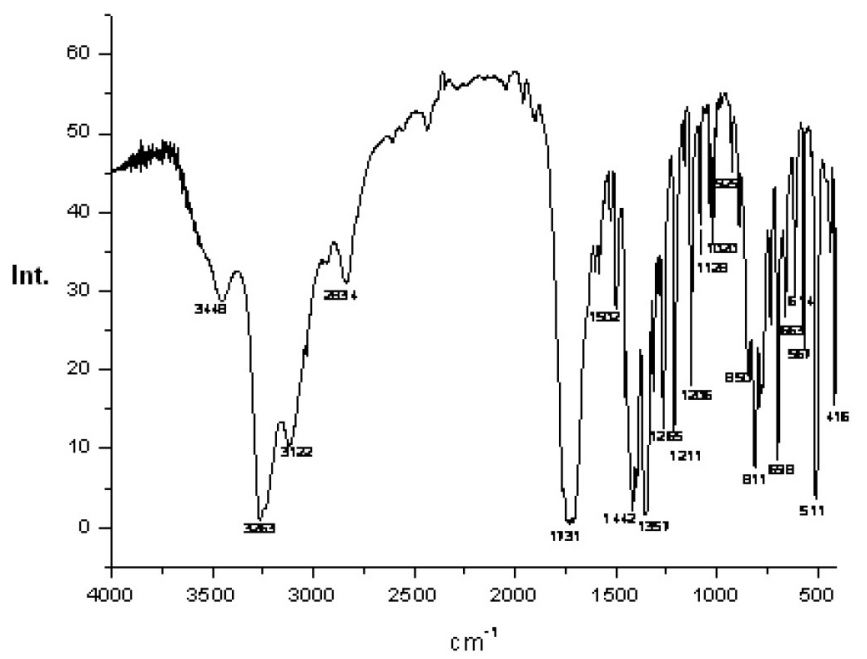

Figure S3. IR spectrum of $\mathbf{6 a}$.

\section{Compound 6b}
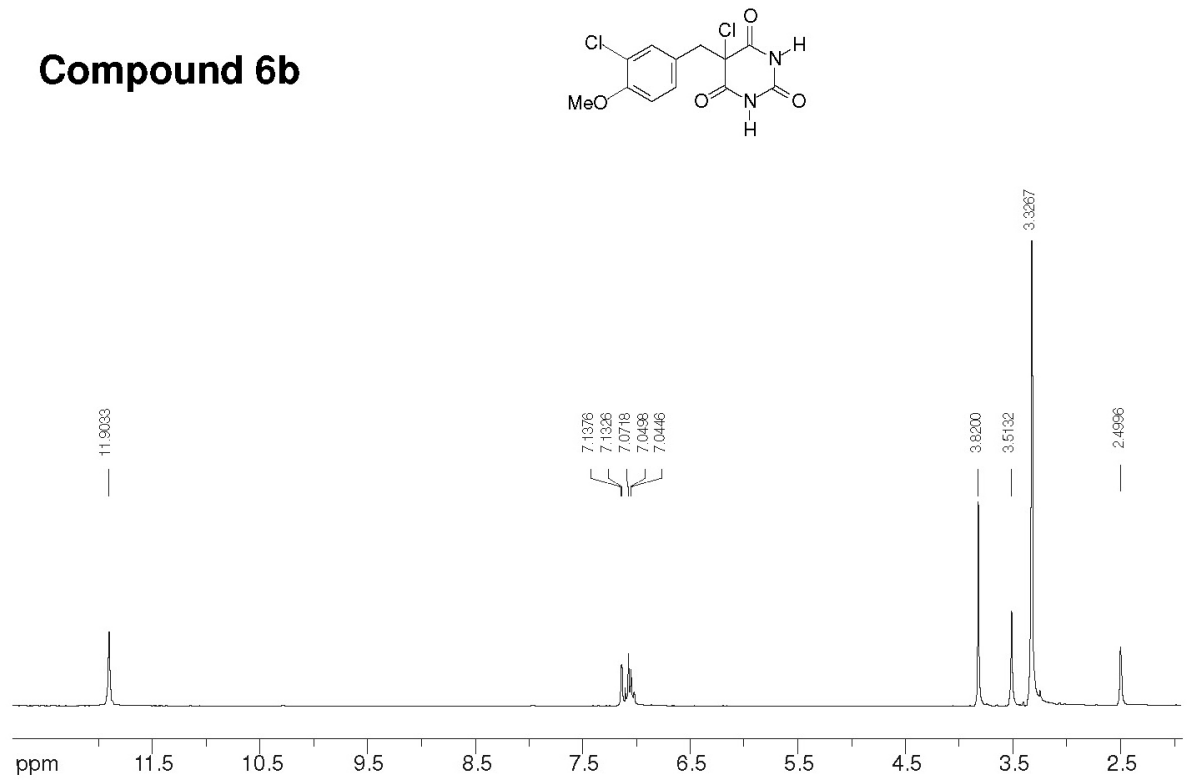

Figure 4. ${ }^{1} \mathrm{H}$ NMR spectrum of $\mathbf{6 b}$. 


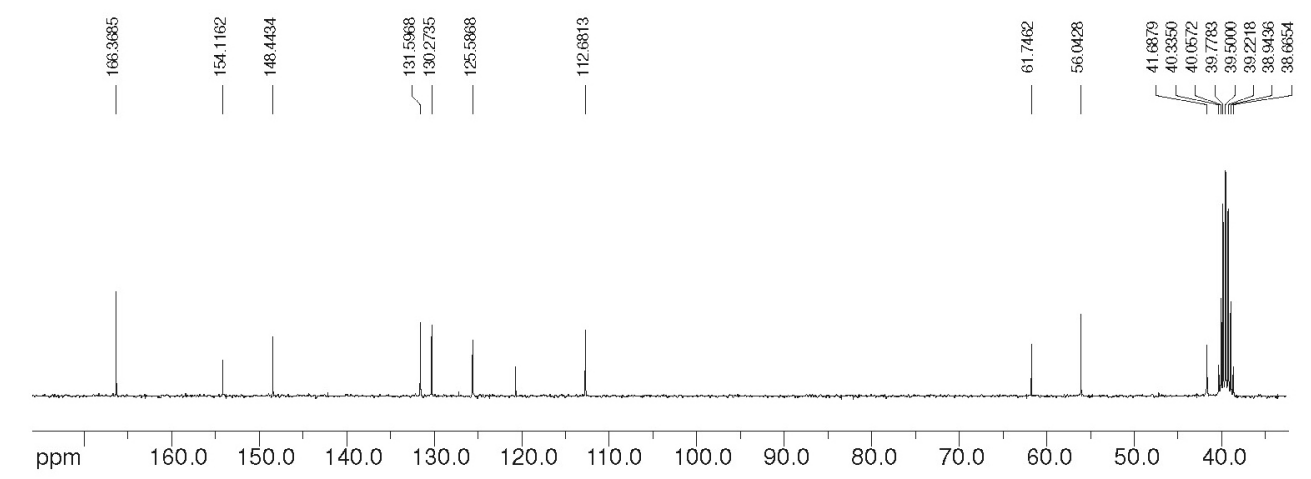

Figure S5. ${ }^{13} \mathrm{C}$ NMR spectrum of $\mathbf{6 b}$.

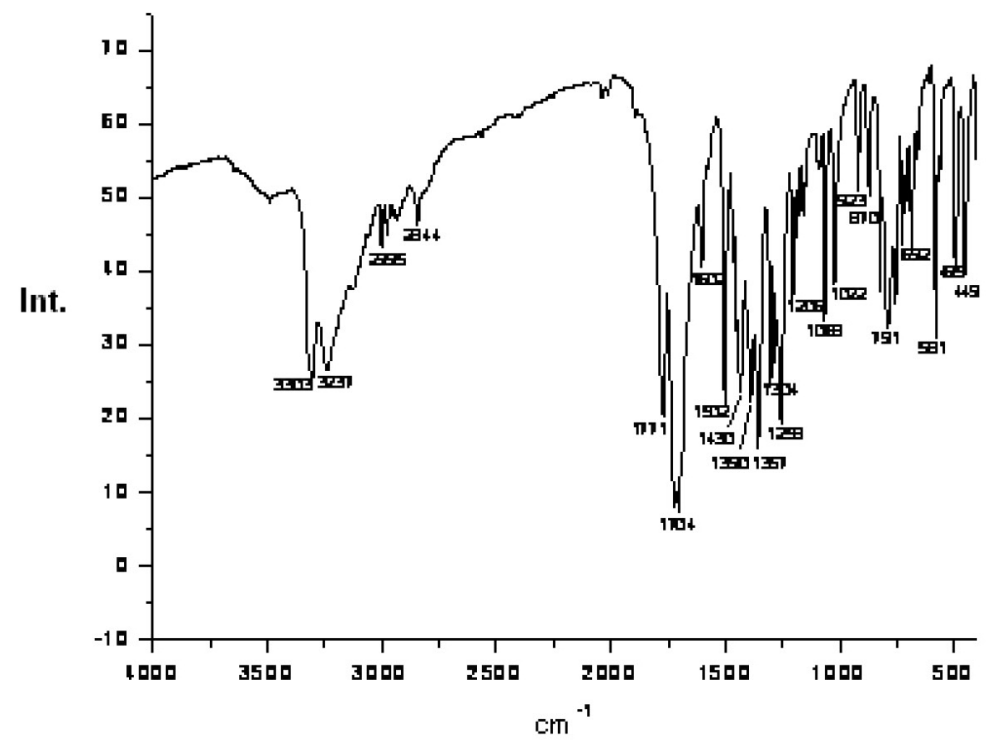

Figure S6. IR spectrum of $6 \mathbf{b}$. 


\section{Compound $6 \mathrm{c}$}
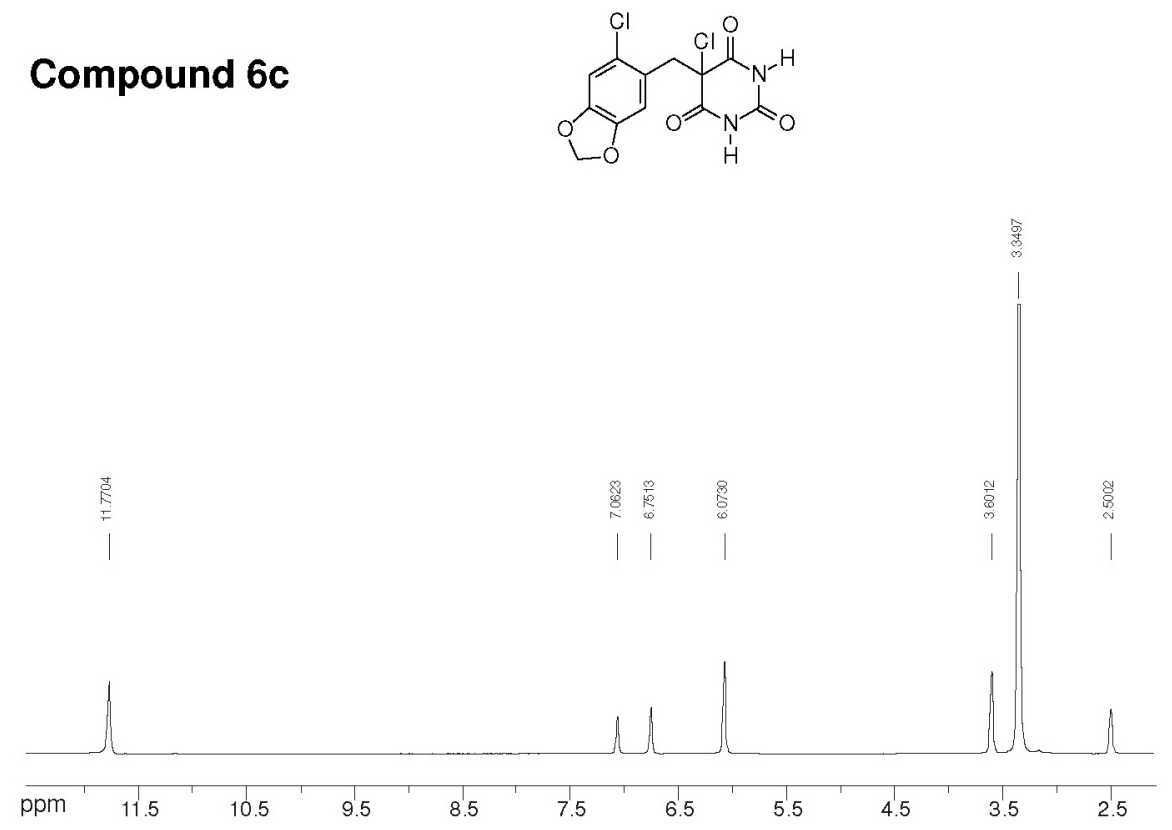

Figure S7. ${ }^{1} \mathrm{H}$ NMR spectrum of $\mathbf{6 c}$.

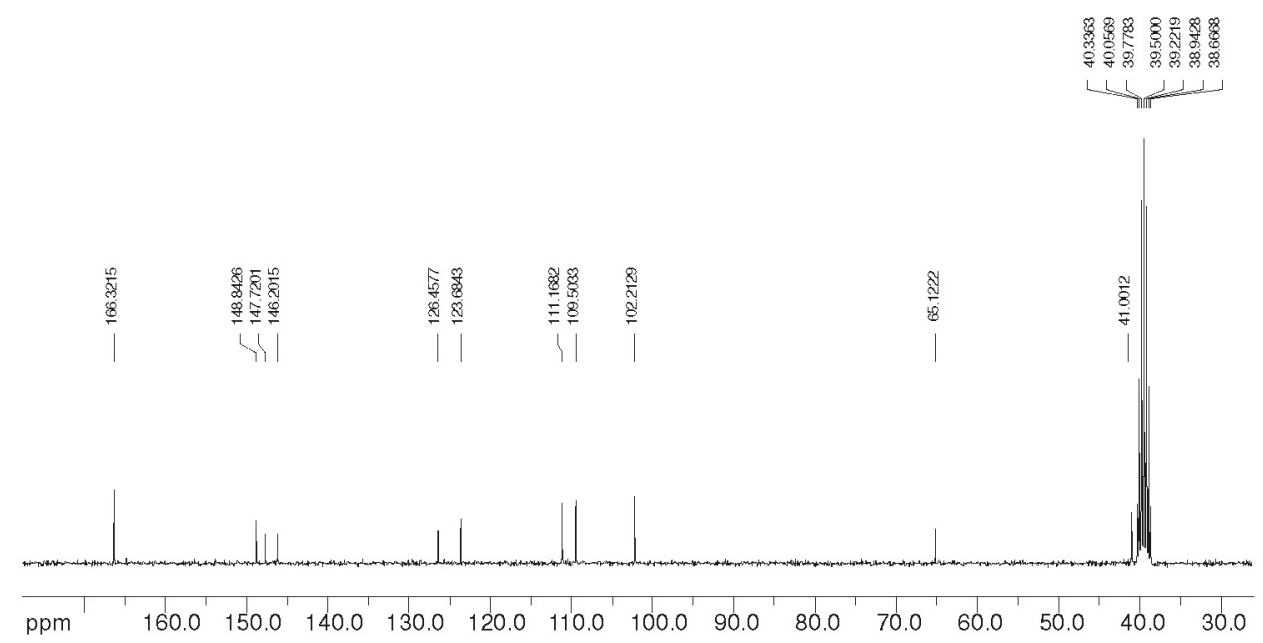

Figure S8. ${ }^{13} \mathrm{C}$ NMR spectrum of $\mathbf{6 c}$. 


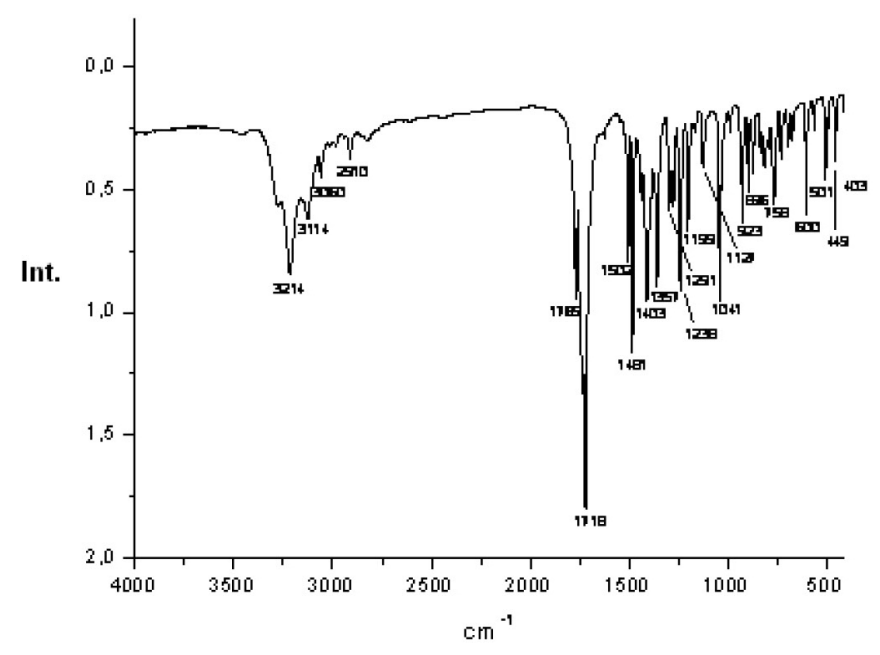

Figure S9. IR spectrum of $\mathbf{6 c}$.

\section{Compound 6d}
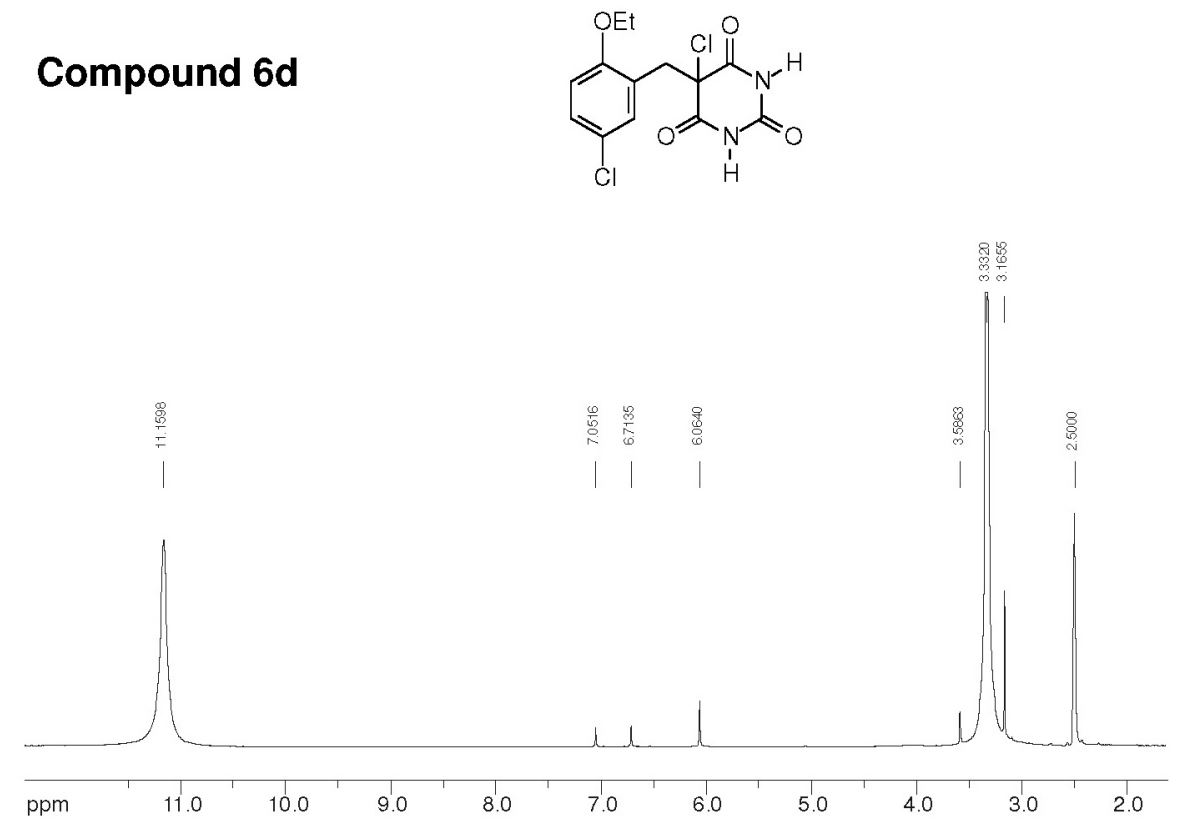

Figure S10. ${ }^{1} \mathrm{H}$ NMR spectrum of $\mathbf{6 d}$. 


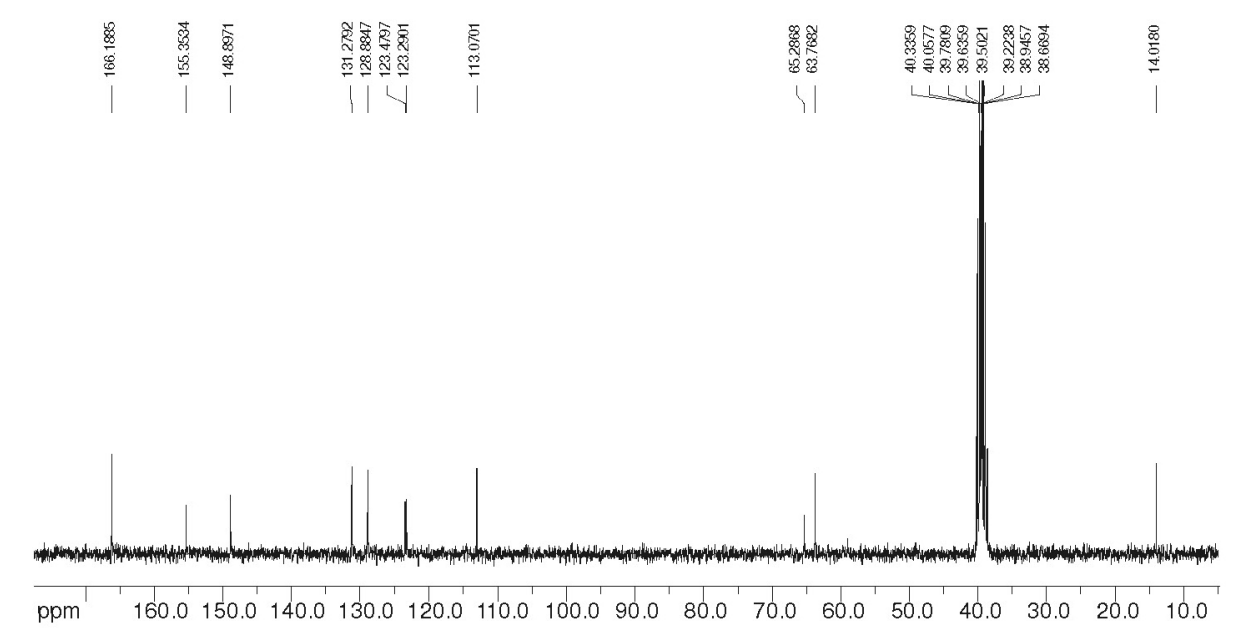

Figure S11. ${ }^{13} \mathrm{C}$ NMR spectrum of $\mathbf{6 d}$.

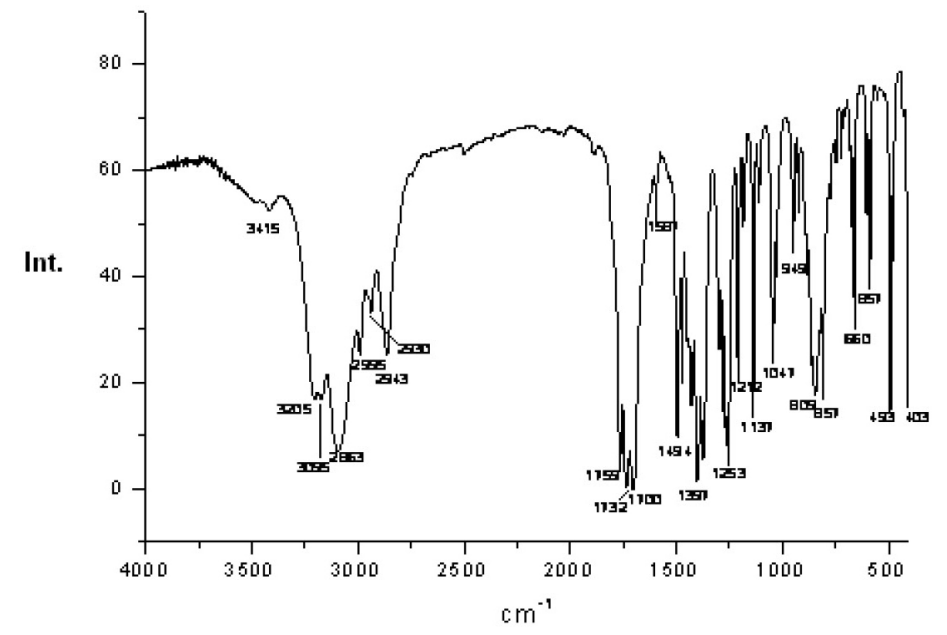

Figure S12. IR spectrum of 6 d. 
Vol. 22, No. 2, 2011

Vieira et al.
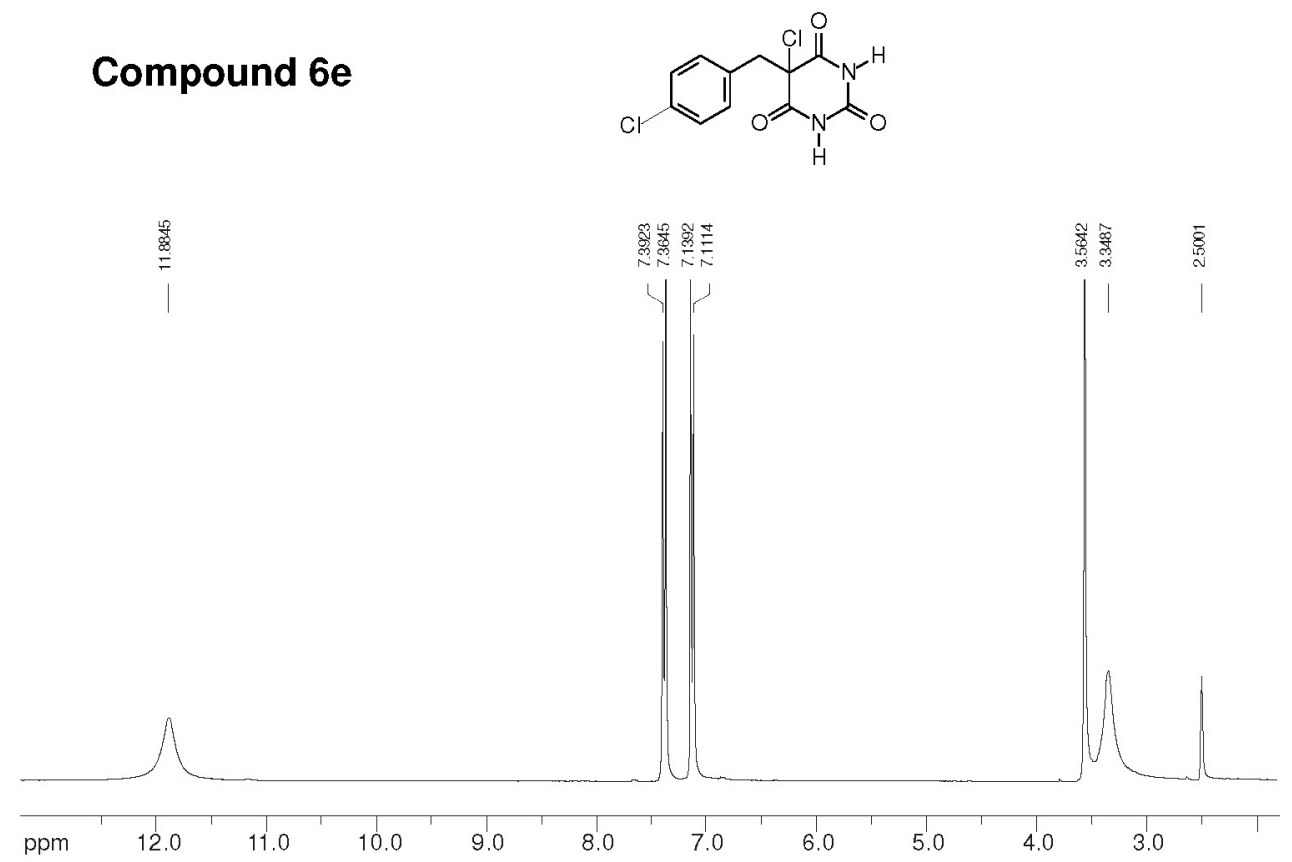

Figure S13. ${ }^{1} \mathrm{H}$ NMR spectrum of 6 e.

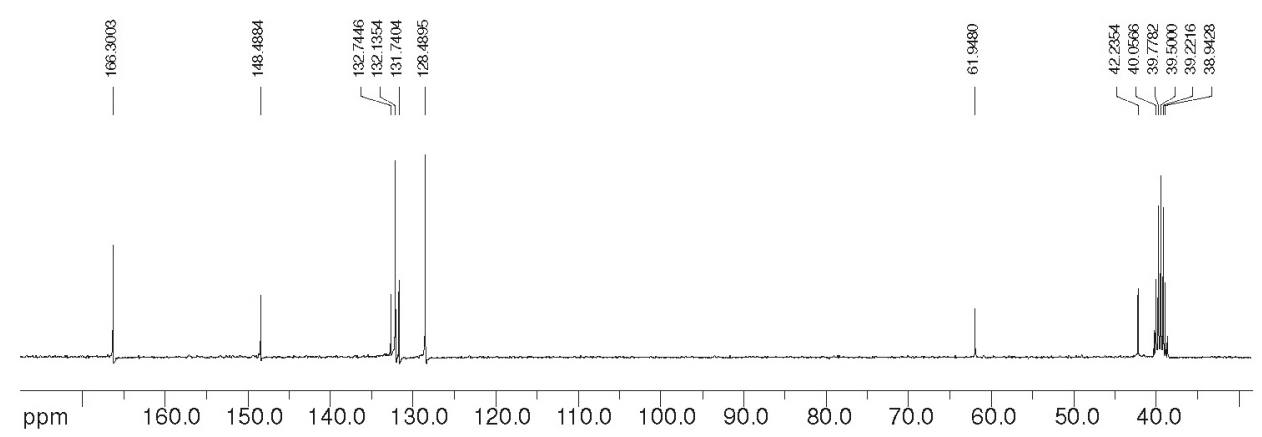

Figure S14. ${ }^{13} \mathrm{C}$ NMR spectrum of 6 e. 


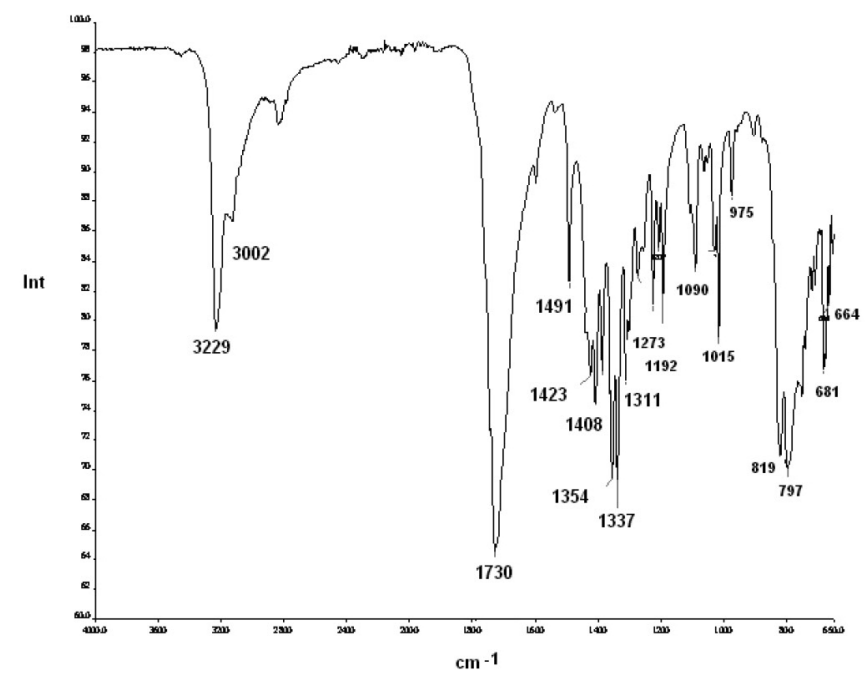

Figure S15. IR spectrum of 6 e.

\section{Compound $6 f$}

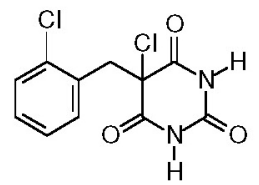

$\stackrel{\stackrel{\infty}{0}}{\stackrel{\substack{8 \\ \hdashline}}{=}}$

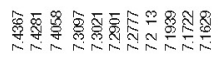
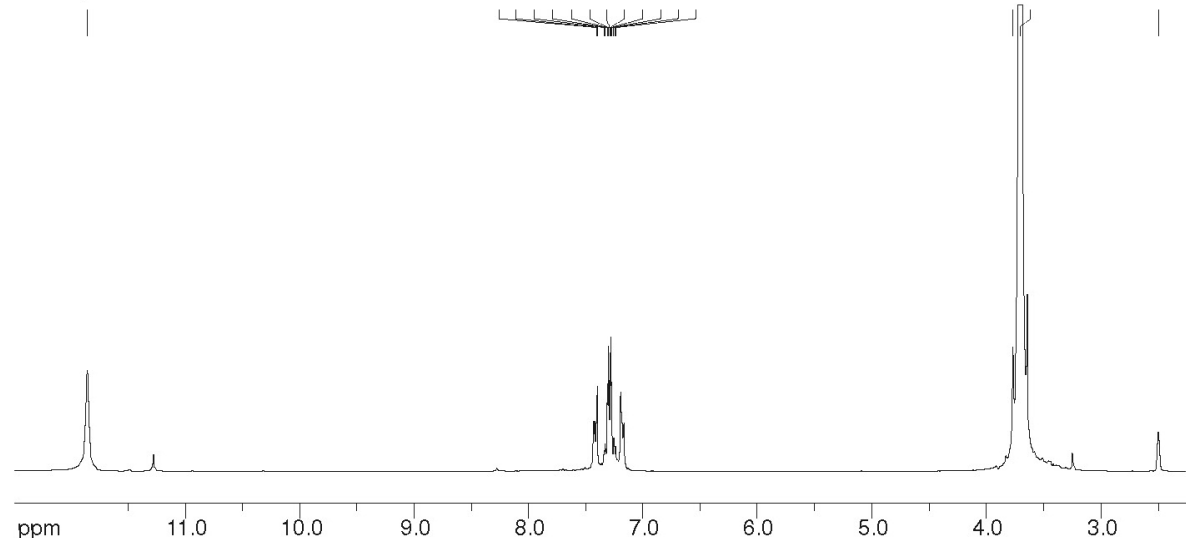

Figure S16. ${ }^{1} \mathrm{H}$ NMR spectrum of $\mathbf{6}$. 

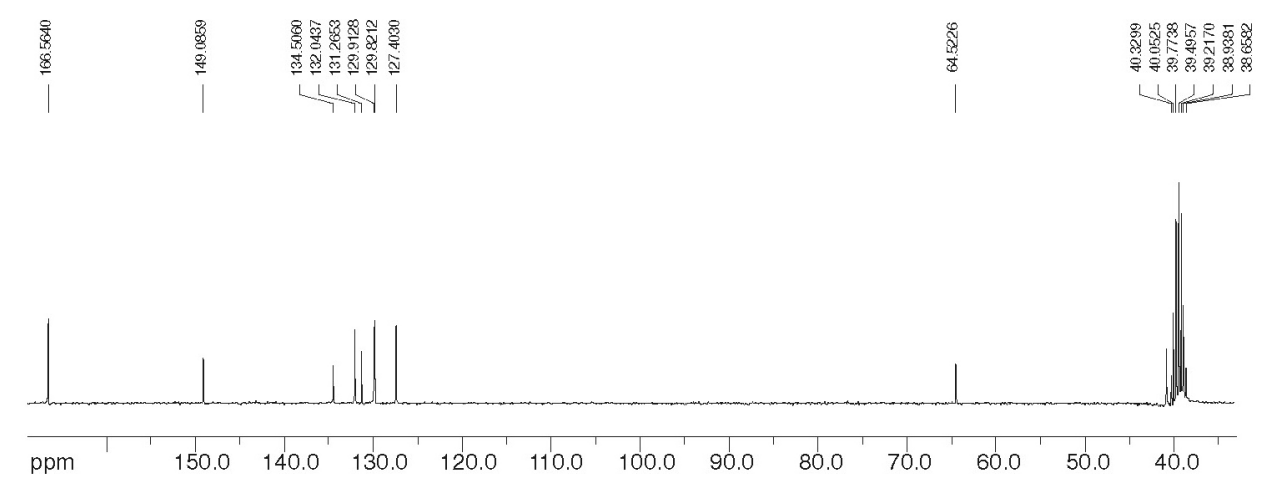

Figure S17. ${ }^{13} \mathrm{C}$ NMR spectrum of $6 \mathbf{f}$.

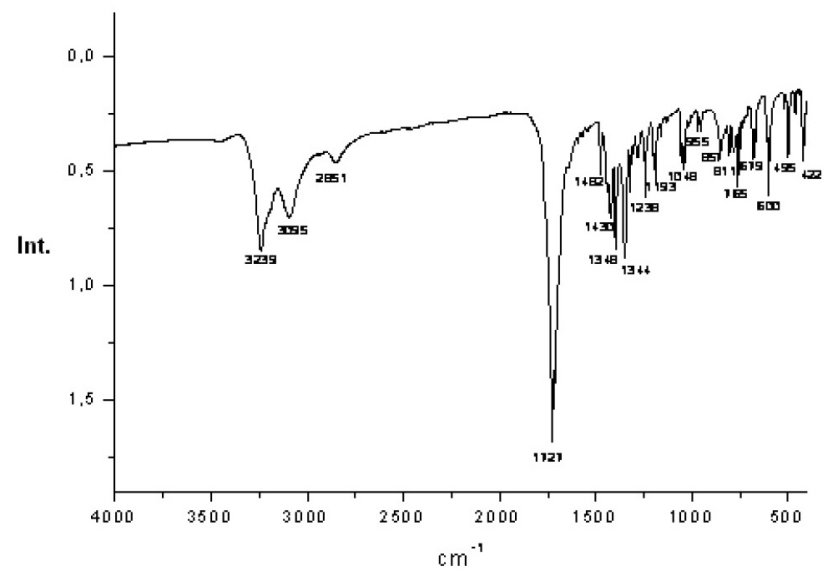

Figure S18. IR spectrum of $6 \mathbf{f}$. 
Table S1. ${ }^{1} \mathrm{H}$ NMR signal assignment for compounds $\mathbf{6 a}$ to $\mathbf{6} \mathbf{f}$

\begin{tabular}{lcccccc}
\hline Comp. & $\mathbf{6 a}$ & $\mathbf{6 b}$ & $\mathbf{6 c}$ & $\mathbf{6 d}$ & $\mathbf{6 e}$ & 6f \\
\hline $\mathrm{H} 1+\mathrm{H} 3$ & $11.20(2 \mathrm{H}, \mathrm{s})$ & $11.90(2 \mathrm{H}, \mathrm{s})$ & $11.77(2 \mathrm{H}, \mathrm{s})$ & $11.66(2 \mathrm{H}, \mathrm{s})$ & $11.88(2 \mathrm{H} . \mathrm{s})$ & $11.85(2 \mathrm{H}, \mathrm{s})$ \\
$\mathrm{H} 7$ & $3.57(2 \mathrm{H}, \mathrm{s})$ & $3.50(2 \mathrm{H}, \mathrm{s})$ & $3.59(2 \mathrm{H}, \mathrm{s})$ & $3.52(2 \mathrm{H}, \mathrm{s})$ & $3.55(2 \mathrm{H} . \mathrm{s})$ & $4.00(2 \mathrm{H}, \mathrm{s})$ \\
$\mathrm{H} 9$ & $7.09(2 \mathrm{H}, \mathrm{d}, J 3.6 \mathrm{~Hz})$ & $7.11(1 \mathrm{H}, \mathrm{s}) ;$ & $7.05(1 \mathrm{H}, \mathrm{s})$ & - & $7.11(2 \mathrm{H} . \mathrm{d} . J 8.4 \mathrm{~Hz})$ & - \\
$\mathrm{H} 10$ & $7.29(3 \mathrm{H}, \mathrm{t}, J 3.6 \mathrm{~Hz})$ & - & - & $6.95(1 \mathrm{H}, \mathrm{d}, J 4.3 \mathrm{~Hz})$ & $7.37(2 \mathrm{H} . \mathrm{d} . J 8.4 \mathrm{~Hz})$ & $7.27(2 \mathrm{H}, \mathrm{t}, J 3.2 \mathrm{~Hz})$ \\
$\mathrm{H} 11$ & $7.29(3 \mathrm{H}, \mathrm{t}, J 3.6 \mathrm{~Hz})$ & - & - & $7.28(1 \mathrm{H}, \mathrm{d}, J 4.3 \mathrm{~Hz})$ & - & $7.27(2 \mathrm{H}, \mathrm{t}, J 3.2 \mathrm{~Hz})$ \\
$\mathrm{H} 12$ & $7.29(3 \mathrm{H}, \mathrm{t}, J 3.6 \mathrm{~Hz})$ & $7.00(1 \mathrm{H}, \mathrm{d}, J 6.0 \mathrm{~Hz})$ & $6.74(1 \mathrm{H}, \mathrm{s})$ & - & $7.37(2 \mathrm{H} . \mathrm{d} . J 8.4 \mathrm{~Hz})$ & $7.40(1 \mathrm{H}, \mathrm{d}, J 3.8 \mathrm{~Hz})$ \\
$\mathrm{H} 13$ & $7.09(2 \mathrm{H}, \mathrm{d}, J 3.6 \mathrm{~Hz})$ & $7.05(1 \mathrm{H}, \mathrm{d}, J 6.0 \mathrm{~Hz}) ;$ & - & $7.11(1 \mathrm{H}, \mathrm{s}) ;$ & $7.11(2 \mathrm{H} . \mathrm{d} . J 8.4 \mathrm{~Hz})$ & $7.17(1 \mathrm{H}, \mathrm{d}, J 3.5 \mathrm{~Hz})$ \\
$\mathrm{Me}$ & - & $3.82(3 \mathrm{H}, \mathrm{s}) ;$ & - & $1.29(3 \mathrm{H}, \mathrm{t}, J 5.0 \mathrm{~Hz})$ & - & - \\
$\mathrm{CH}$ & - & - & $6.07(2 \mathrm{H}, \mathrm{s})$ & $3.94(2 \mathrm{H}, \mathrm{q}, J 4.5 \mathrm{~Hz})$ & - & - \\
\hline
\end{tabular}

Table S2. ${ }^{13} \mathrm{C}$ NMR signal assignment for compounds $\mathbf{6 a}$ to $\mathbf{6 f}$

\begin{tabular}{|c|c|c|c|c|c|c|}
\hline Comp. & $6 a$ & $6 \mathrm{~b}$ & $6 c$ & $6 d$ & $6 e$ & $6 f$ \\
\hline $\mathrm{C} 2$ & 148.4 & 148.5 & 148.7 & 149.0 & 148.5 & 149.1 \\
\hline $\mathrm{C} 4+\mathrm{C} 6$ & 166.4 & 166.4 & 166.3 & 166.9 & 166.3 & 166.6 \\
\hline C5 & 61.9 & 61.8 & 65.2 & 65.3 & 61.9 & 64.3 \\
\hline C7 & 43.5 & 41.7 & 41.0 & 39.6 & 42.2 & 40.8 \\
\hline $\mathrm{C} 8$ & 132.5 & 120.7 & 126.2 & 123.3 & 131.7 & 131.3 \\
\hline C9 & 128.6 & 130.3 & 109.5 & 155.4 & 132.1 & 134.5 \\
\hline $\mathrm{C} 10$ & 130.1 & 125.6 & 146.1 & 113.1 & 128.5 & 132.1 \\
\hline C11 & 128.0 & 154.1 & 147.9 & 128.9 & 132.7 & 127.4 \\
\hline $\mathrm{C} 12$ & 130.1 & 112.7 & 111.2 & 123.5 & 128.5 & 129.8 \\
\hline C13 & 128.6 & 131.6 & 123.8 & 131.3 & 132.1 & 129.9 \\
\hline $\mathrm{CH}_{2}$ & - & - & 102.2 & 63.8 & - & - \\
\hline $\mathrm{CH}_{3}$ & - & 56.1 & - & 14.0 & - & - \\
\hline
\end{tabular}

